
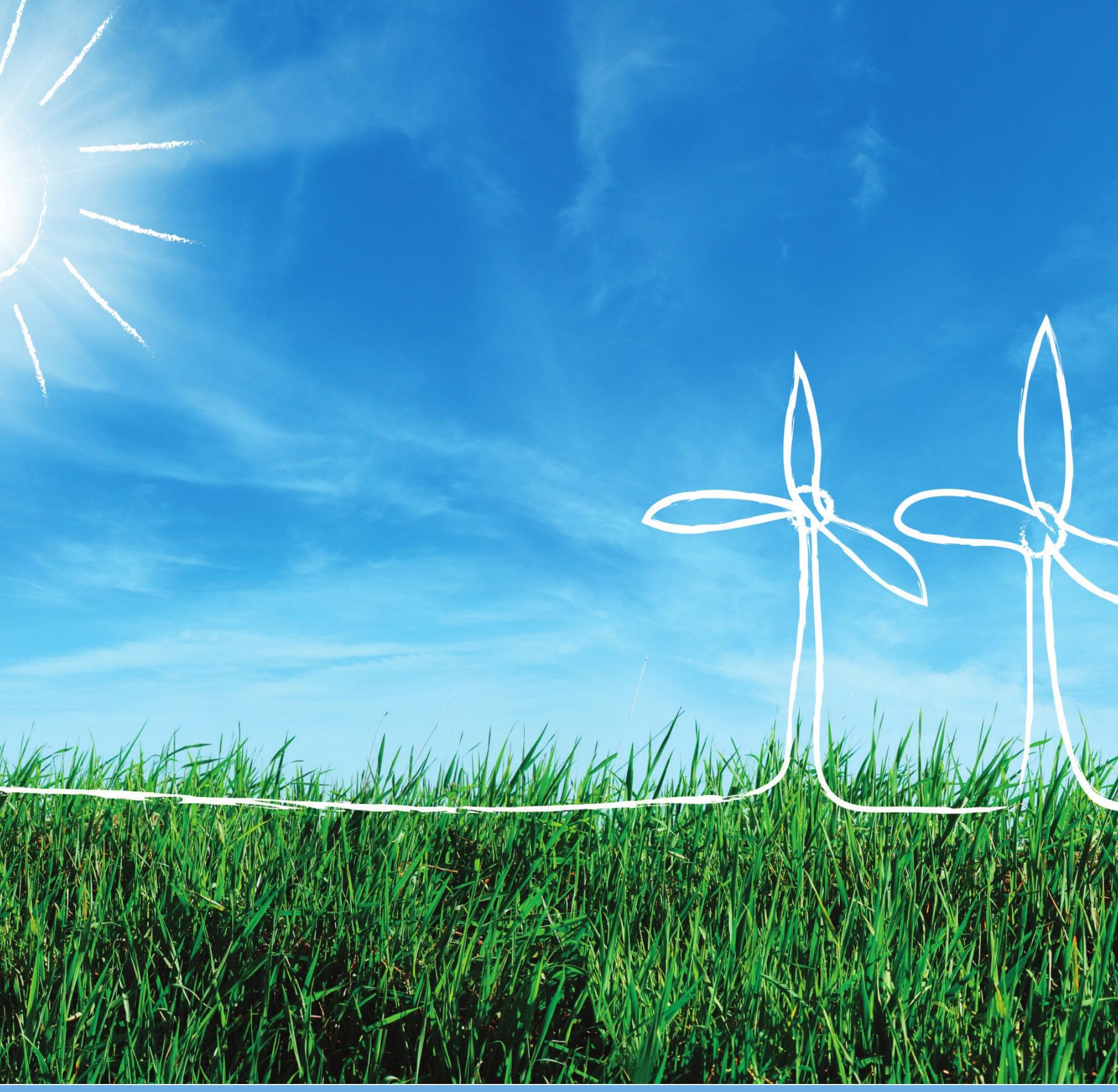

\title{
Duurzaamheid van de ethanol productie bij een combinatie van suikerbieten en snijmaïs
}

Gevoeligheidsanalyse 


\section{Duurzaamheid van de ethanol productie bij een combinatie van suikerbieten en snijmaïs}

Gevoeligheidsanalyse

\section{Auteurs}

Stefan Hol \& Chris de Visser

Wageningen University \& Research

Dit onderzoek is uitgevoerd binnen het Demonstratie Energie- en Klimaatinnovatie (DEI) subsidie programma van de Rijksdienst voor Ondernemend Nederland (RVO) uitgevoerd door de Stichting Wageningen Research (WR).

WR is een onderdeel van Wageningen University \& Research, samenwerkingsverband tussen Wageningen University en de Stichting Wageningen Research.

Wageningen, Oktober 2020

Rapport WPR-849 
Hol, S.J.E., Visser, C.L.M. de, 2020. Duurzaamheid van de ethanol productie bij een combinatie van suikerbieten en snijmaïs; Gevoeligheidsanalyse. Wageningen Research, Rapport WPR-849

Dit rapport is gratis te downloaden op https://doi.org/10.18174/534523

Door onze klimaatdoelstellingen is de vraag naar bio-ethanol steeds groter aan het worden. Er zijn steeds meer manieren en grondstoffen om bio-ethanol te produceren. Daarom is belangrijk om bij een nieuw productieconcept de mate van duurzaamheid te bepalen en die af te zetten tegen de standaard. Een bio-ethanol fabriek met een lagere broeikasgasuitstoot is niet alleen beter voor het milieu, maar kan ook financieel aantrekkelijker zijn wanneer bedrijven hun milieu impact willen verkleinen door anders in te kopen. Dit rapport heeft als vertrekpunt het direct processing van suikerbieten en wanneer er geen suikerbieten meer zijn snijmais fermentatie tot ethanol. De milieutechnische duurzaamheid van de productie van bio-ethanol bij dit gecombineerd gebruik van suikerbieten en snijmaiskorrels is via een modelstudie berekend. Het resultaat was een gemiddelde uitstoot van 23.29 gram CO2 equivalenten per MJ ethanol. Dit is lager dan de 23.9 gram CO2 equivalenten per MJ ethanol beschreven in de Renewable Energy Directive voor ethanolproductie op basis van suikerbieten. Daarnaast is gekeken hoe gevoelig de broeikasgas (BKG) emissie per MJ ethanol is voor veranderingen in een aantal parameters die in het model zijn opgenomen. De grootste veranderingen van de BKG uitstoot per MJ ethanol is gevonden bij de omzettingsefficiëntie van suiker naar ethanol tijdens de fermentatie. Maar ook de opbrengst van suikerbieten \& snijmais per hectare en het suikergehalte van de suikerbieten hebben een substantieel effect. Daarnaast heeft het energieverbruik van het suikerbieten verwerkingsproces een groot effect. Al deze processen zijn te sturen doormiddel van teelt aanpassingen, eventueel veredeling van suikerbieten of gisten en proces optimalisatie. Naast de gevoeligheid van de uitstoot voor bepaalde veranderingen in parameters kwam als belangrijke observatie uit deze studie dat een kleinere fabriek milieutechnisch interessanter is. Daarnaast kan geconcludeerd worden dat ethanol uit snijmais milieutechnisch beter is dan ethanol uit suikerbieten

Trefwoorden: bio-ethanol, gevoeligheidsanalyse, broeikasgas, emissie, snijmais, suikerbiet, sustainability

(C) 2020 Wageningen, Stichting Wageningen Research, Wageningen Plant Research, Business unit Open Teelten, Postbus 430, 8200 AK Lelystad; T 0320291 111; www.wur.nl/plant-research

KvK: 09098104 te Arnhem

VAT NL no. 8113.83.696.B07

Stichting Wageningen Research. Alle rechten voorbehouden. Niets uit deze uitgave mag worden verveelvoudigd, opgeslagen in een geautomatiseerd gegevensbestand, of openbaar gemaakt, in enige vorm of op enige wijze, hetzij elektronisch, mechanisch, door fotokopieën, opnamen of enige andere manier zonder voorafgaande schriftelijke toestemming van Stichting Wageningen Research.

Stichting Wageningen Research is niet aansprakelijk voor eventuele schadelijke gevolgen die kunnen ontstaan bij gebruik van gegevens uit deze uitgave.

Rapport WPR-849 



\section{Inhoud}

$\begin{array}{ll}\text { Samenvatting } & 1\end{array}$

1

Inleiding $\quad 2$

1.1 Doel 2

2

$\begin{array}{ll}\text { Achtergrond informatie } & 3\end{array}$

2.1 Beschrijving van het proces 3

2.2 Direct processing 3

2.3 Mais fermentatie proces 4

2.4 Referentiewaarde 5

3

$\begin{array}{ll}\text { Het model } & 7\end{array}$

$\begin{array}{lll}3.1 & \text { Aannames } & 7\end{array}$

3.2 Parameters $\quad 8$

3.3 Variabelen $\quad 12$

3.4 De formules $\quad 12$

3.4.1 Grondstof gerelateerde berekeningen 13

$\begin{array}{ll}3.4 .2 & \text { Algemene berekeningen per gewas }\end{array}$

$\begin{array}{ll}3.4 .3 \text { Teelt uitstoot } & 14\end{array}$

$\begin{array}{ll}3.4 .4 \text { Verwerking uitstoot } & 15\end{array}$

3.4.5 Transport uitstoot 16

3.4.6 Extra outputs 16

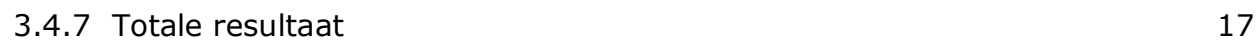

$\begin{array}{llr}4 & \text { Resultaten en discussie } & 18\end{array}$

$\begin{array}{lll}4.1 & \text { Resultaten en discussie op de resultaten } & 18\end{array}$

4.2 Discussie op het model $\quad 21$

$5 \quad$ Conclusie \& aanbevelingen $\quad 24$

$\begin{array}{ll}\text { Literatuur } & 25\end{array}$

$\begin{array}{lr}\text { Bijlagen } & \mathbf{2 7}\end{array}$

$\begin{array}{lll}\text { Bijlage } 1 & \text { Energieberekeningen BetaProces } & 28\end{array}$

Bijlage 2 Energieberekeningen snijmaisfermentatie proces 31 


\section{Samenvatting}

Door onze klimaatdoelstellingen is de vraag naar bio-ethanol steeds groter aan het worden. Er zijn steeds meer manieren en grondstoffen om bio-ethanol te produceren. Daarom is belangrijk om bij een nieuw productieconcept de mate van duurzaamheid te bepalen en die af te zetten tegen de standaard. Een bio-ethanol fabriek met een lagere broeikasgasuitstoot is niet alleen beter voor het milieu, maar kan ook financieel aantrekkelijker zijn wanneer bedrijven hun milieu impact willen verkleinen door anders in te kopen. Dit rapport heeft als vertrekpunt het direct processing van suikerbieten en wanneer er geen suikerbieten meer zijn snijmais fermentatie tot ethanol. De milieutechnische duurzaamheid van de productie van bio-ethanol bij dit gecombineerd gebruik van suikerbieten en snijmaiskorrels is via een modelstudie berekend. Het resultaat was een gemiddelde uitstoot van 23.29 gram CO2 equivalenten per MJ ethanol. Dit is lager dan de 23.9 gram CO2 equivalenten per MJ ethanol beschreven in de Renewable Energy Directive voor ethanolproductie op basis van suikerbieten. Daarnaast is gekeken hoe gevoelig de broeikasgas (BKG) emissie per MJ ethanol is voor veranderingen in een aantal parameters die in het model zijn opgenomen. De grootste veranderingen van de BKG uitstoot per MJ ethanol is gevonden bij de omzettingsefficiëntie van suiker naar ethanol tijdens de fermentatie. Maar ook de opbrengst van suikerbieten \& snijmais per hectare en het suikergehalte van de suikerbieten hebben een substantieel effect. Daarnaast heeft het energieverbruik van het suikerbieten verwerkingsproces een groot effect. Al deze processen zijn te sturen doormiddel van teelt aanpassingen, eventueel veredeling van suikerbieten of gisten en proces optimalisatie. Naast de gevoeligheid van de uitstoot voor bepaalde veranderingen in parameters kwam als belangrijke observatie uit deze studie dat een kleinere fabriek milieutechnisch interessanter is. Daarnaast kan geconcludeerd worden dat ethanol uit snijmais milieutechnisch beter is dan ethanol uit suikerbieten. 


\section{$1 \quad$ Inleiding}

Bio-ethanol kan zonder problemen toegevoegd worden aan benzine, zoals momenteel gebeurt bij de E10 brandstoffen. In deze E10 brandstoffen zit tot 10\% bio-ethanol. Daarnaast is ethanol een belangrijke grondstof voor de chemische en farmaceutische industrie. Het wordt gebruikt in cosmetica, oplos- en schoonmaakmiddelen, verven en plastics. Van origine wordt de ethanol uit deze sectoren vooral uit aardolie gemaakt (Schipperus \& Spruijt, 2013). Echter is dit een erg energie intensief en hoog $\mathrm{CO} 2$ uitstotend proces. Door onze klimaatdoelstellingen is de vraag naar bio-ethanol steeds groter aan het worden.

Volgens de belangenorganisatie van Europese hernieuwbare ethanol producenten (ePure) wordt 43\% van de Europese bio-ethanol gemaakt uit snijmais (2018). Echter er worden ook andere gewassen gebruikt als grondstof, zoals suikerriet en tarwe. Maar eigenlijk alle biomassa met suiker of zetmeel verbindingen kan gebruikt worden. Het lijkt logisch om de positie in te nemen dat bio-ethanol een milieuvriendelijker alternatief is in vergelijking met aardolie ethanol zoals Ballat \& Ballat (2009) beschrijven. Dat laat onverlet dat het belangrijk is om bij een nieuw productieconcept de mate van duurzaamheid te bepalen en die af te zetten tegen de standaard. Daarbij is ook belangrijk om te weten in welke mate die duurzaamheid afhankelijk is van allerlei parameters in dat nieuwe concept. Een bio-ethanol fabriek met een lagere broeikasgasuitstoot is niet alleen beter voor het milieu, maar kan ook financieel aantrekkelijker zijn wanneer bedrijven hun milieu impact willen verkleinen door anders in te kopen. Dit rapport heeft als vertrekpunt een nieuw productieconcept van ethanol op basis van suikerbieten. Om te bepalen of dit proces duurzamer is dan de huidige standaard is deze model studie gedaan. Omdat suikerbieten lastig jaarrond te bewaren zijn en het wel van belang is een fabriek gebaseerd op dit concept jaarrond te laten draaien, hebben we het productieconcept uitgebreid met een grondstof die makkelijk te bewaren is en zoveel mogelijk binnen dat concept past. De keuze is hierbij gevallen op snijmaïs.

\subsection{Doel}

In dit rapport wordt onderzocht welke parameters de belangrijkste invloed hebben op de milieutechnische duurzaamheid van de productie van bio-ethanol bij een gecombineerd gebruik van suikerbieten en snijmaiskorrels. Dit is gedaan aan de hand van een modelstudie met gevoeligheidsanalyses voor de individuele parameters. Door te achterhalen welke parameters het grootste effect hebben op de duurzaamheidscore van het totale verwerkingsproces kan de duurzaamheid van het proces beter gestuurd worden. 


\section{Achtergrond informatie}

\subsection{Beschrijving van het proces}

De basis van het proces is het fermenteren van suikerbieten naar ethanol met het productieconcept van direct processing (zie hoofdstuk 2.2). Aangezien suikerbieten slechts beperkt bewaarbaar zijn (suikergehalte loopt terug en rot treedt op) kan een fabriek gebaseerd op suikerbieten niet jaarrond produceren, althans niet bij direct processing. In de praktijk wordt dit bewaarprobleem opgevangen door bewaarbaar diksap te produceren zodat jaarrond ethanol geproduceerd kan worden (Buchspies \& Kaltschmitt, 2016). In het productieconcept onder studie, wordt het bewaarprobleem opgelost door in de fabriek maïskorrels te verwerken die goed bewaarbaar zijn, zodat de fabriek jaarrond ethanol kan produceren. Dit is inzichtelijk gemaakt in onderstaande figuur (zie Figuur 1). De verwerking van de snijmaiskorrels zal grotendeels plaatsvinden door gebruik te maken van hetzelfde proces als waarmee de bieten worden verwerkt (zie hoofdstuk 2.3). Snijmaiskorrels zijn geschikt voor lange termijn bewaring en is een bekende bron voor ethanol productie met een opbrengst van ruim 380 liter per ton mais (Turhollow \& Heady, 1986).

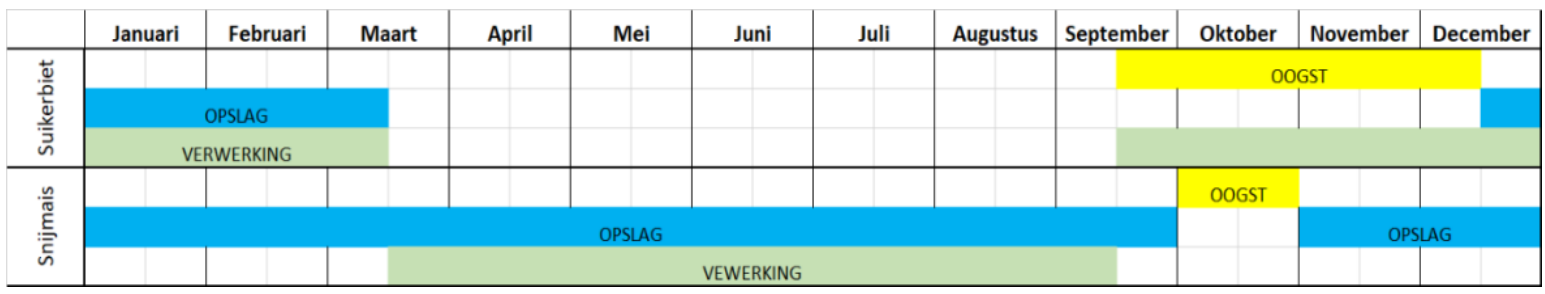

Figuur 1 Globaal schematisch jaaroverzicht van momenten van oogst (geel), opslag (blauw) en verwerking (groen) van suikerbieten en snijmais

\section{$2.2 \quad$ Direct processing}

Momenteel worden suikerbieten voornamelijk verwerkt tot kristalsuiker. Na de oogst worden de bieten geschild en gesneden om vervolgens gekookt te worden. Hier komt een brij uit genaamd ruwsap dat vervolgens ingedikt wordt tot het goed bewaarbare diksap. In dit sap zit de suiker opgelost wat verder geraffineerd wordt tot kristalsuiker, maar dit kan ook gebruikt worden om bio-ethanol te maken. De bietenpulp die overblijft kan gebruikt worden als veevoer of als grondstof voor de productie van biogas (Rector, 2015).

DSD BV heeft een bio-ethanol productieproces ontwikkeld waarin directe verwerking van de suikerbiet plaatsvindt. Dus niet via de gebruikelijke diksap route. De bieten worden eerst gewassen, vervolgens vermalen om door het betaprocess te gaan. In deze stap worden de suikerbieten verwarmd tot $65^{\circ} \mathrm{C}$ om vervolgens in een vacuum kamer te komen met een druk van -930 mbar (ten opzichten van atmosferische druk). Na deze stap wordt het materiaal naar de fermentor gepompt (Figuur 2). $\mathrm{Na}$ de fermentor wordt het effluent gedestilleerd om de ethanol eruit te halen, de vaste delen die achterblijven worden vergist tot biogas. Uit de bio-ethanol productie vanuit suikerbiet komen dus twee bruikbare reststromen: bio-ethanol \& biogas. Het essentiële verschil met de diskaproute is dus dat er altijd onverwerkte bieten beschikbaar moeten zijn om dit proces te laten draaien. Het aantal draaiuren is dan beperkt door de periode waarin onverwerkte suikerbieten beschikbaar zijn en dat is van half september tot februari/maart waarbij tot half december bieten aangevoerd kunnen worden vanaf het veld. Daarna is bewaring nodig in een luchtgekoelde bewaarplaats (zie figuur 1 ). Om de kapitaalkosten van de fabriek per liter ethanol te verlagen, is dus een alternatieve grondstof nodig in de periode van februari/maart tot september. Dat kan met snijmaiskorrels.

Het maken van diksap vergt veel energie en dat maakt tot 30\% uit van de totale BKG emissie van de ethanol uit suikerbieten op basis van de diksaproute (Buchspies \& Kaltschmitt, 2016). Op basis hiervan zou direct processing een lagere BKG emissie kunnen hebben. Maar omdat bij BKG emissie 
berekeningen niet gekeken wordt naar de economische component, zijn we in dit rapport uitgegaan van de combinatie suikerbiet/maïs zodat voldoende draaiuren van de installatie gerealiseerd kunnen worden. De vraag is dus of de combinatie suikerbiet/maïs beter scoort op BKG emissie dan de diksap route van suikerbieten.

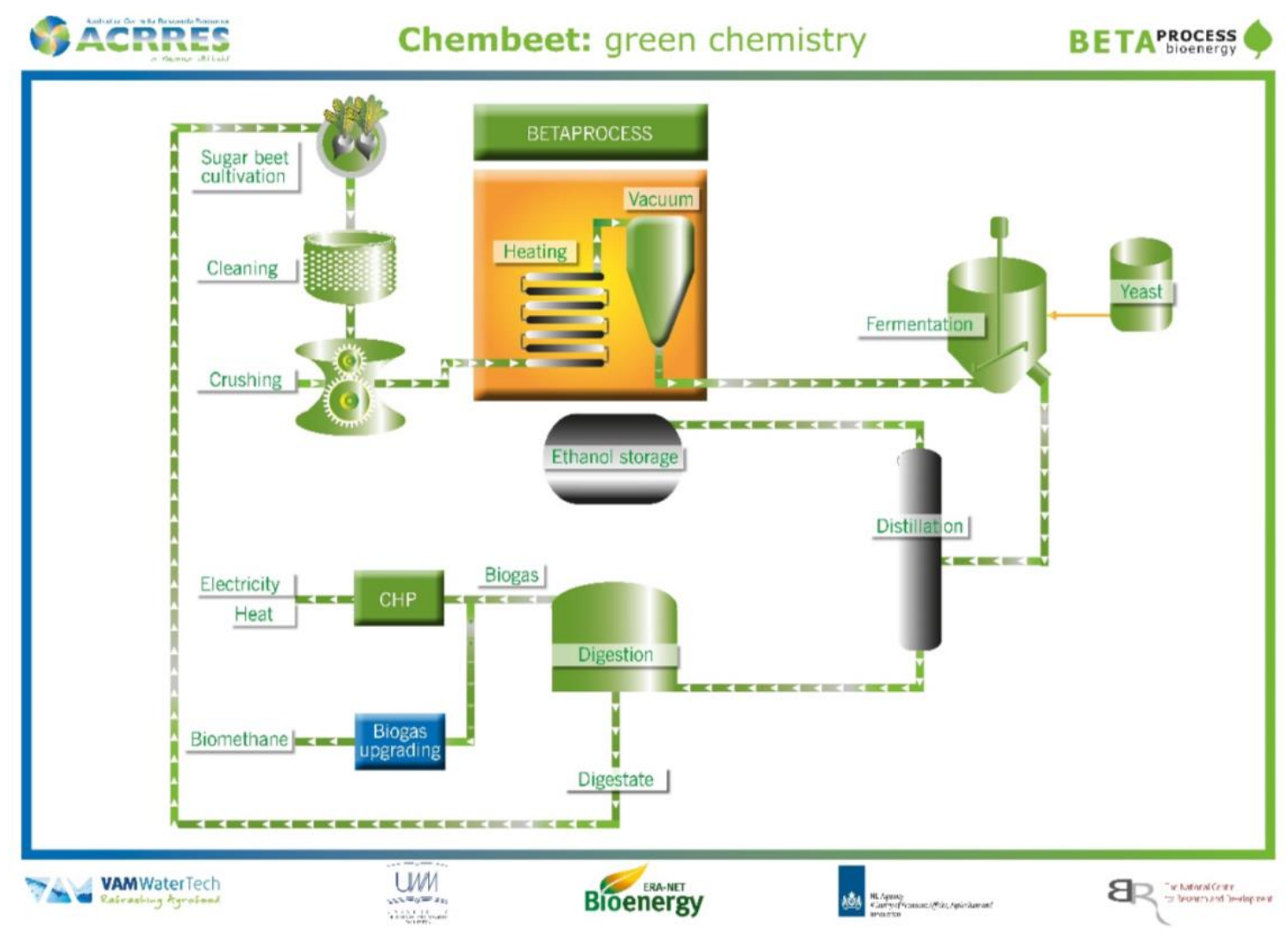

Figuur 2 Schematisch overzicht van het Betaprocess binnen het bio-ethanol proces (Kootstra, 2017)

\subsection{Mais fermentatie proces}

Het best zijn maïskorrels te bewaren als ze droog zijn. In veel gebieden draait de teelt van maïs om de oogst van droge korrels, net zoals dat in Nederland bij graanoogst het geval is, Echter, de meeste Nederlandse maïs is snijmaïs. Bij de oogst van dit gewas worden meestal de kolf, blad en de stengels gezamenlijk verhakseld, opgeslagen en gebruikt als ruwvoer voor melkvee. Om de snijmaïskorrels te kunnen gebruiken voor het ethanolproces, dienen de korrels apart geoogst te worden van de rest van de plant (stengel, blad, spil). Deze snijmaïskorrels zijn nog niet volledig droog en dus minder goed bewaarbaar. Echter, in het verleden is geëxperimenteerd met de opslag van deze korrels in silo's en daarbij bleek een jaarrond bewaarbaarheid mogelijk te zijn (Schipperus \& Spruijt, 2013; Wijnholds et al., 2010). Vanuit de bewaring worden de korrels geweekt in warm water, gecrusht en vervolgens met toevoeging van amylase en gist gefermenteerd. In feite verschilt het proces niet veel van het suikerbieten proces en kan gebruik worden gemaakt van de installaties die nodig zijn voor de suikerbietverwerking. Het stro (blad en stengels) van de snijmaïs worden verhakseld en kan gebruikt worden ten behoeve van de productie van biogas in een vergister, indien maïskorrels gefermenteerd worden voor ethanolproductie, ontstaat een eiwitrijk restproduct zoals dat ook ontstaat bij andere ethanolprocessen op basis van tarwe of maïs, namelijk dried distillers grain with solubles (DDGS). Dit DDGS kan worden gebruikt als veevoer. Uit de bio-ethanol productie vanuit snijmais komen dus drie bruikbare reststromen: bio-ethanol, biogas en veevoer. 


\subsection{Referentiewaarde}

Om het gekozen bio-ethanol proces op waarde te schatten is er een referentie of standaard nodig, hiervoor is gebruik gemaakt van de Renewable Energy Directive (RED). In de RED definieert de Europese Unie een reeks criteria rondom duurzaamheid en broeikasgasemissies specifiek voor het gebruik van vloeibare bio-energie in het vervoer, zoals bio-ethanol. De RED geeft ook de Europese richtlijn per land aan die aangeeft hoeveel procent van het energieverbruik uit hernieuwbare bronnen moet komen. Voor Nederland is deze doelstelling 14\% in 2020, de waarde varieert voor alle landen van de EU afzonderlijk, maar ligt tussen de $10 \%$ voor Malta en de $49 \%$ voor Zweden. De industrie dient aan te tonen, dat zij aan deze streefcijfers bijdragen om in aanmerking te komen voor subsidies van de overheid. Zoals de RVO subsidies: Energie-investeringsaftrek regeling (EIA), de Versnelde klimaatinvesteringen industrie (VEKI) en Milieu-investeringsaftrek (MIA) en de Willekeurige afschrijving milieu-investeringen (Vamil). Deze subsidies worden uitgereikt wanneer men wil investeren in milieuvriendelijkere of $\mathrm{CO} 2$ reducerende maatregelen. Hierdoor is het financieel interessant voor bedrijven om naar producten en processen met een lagere milieu impact te gaan.

Binnen de RED zijn standaard broeikasgasemissiewaarden en rekenregels opgenomen (EU, 2018). De RED onderscheidt standaardwaarden (default) en "werkelijke" (typical) waarden. Uit het gerefereerde document is niet te herleiden hoe de typical waarden zijn bepaald. In onderstaande tabellen zijn de waarden voor ethanol uit suikerbieten (Tabel 1) en mais (Tabel 2) weergegeven. De BKG uitstoot wordt weergegeven in grammen $\mathrm{CO} 2$ equivalenten per $\mathrm{MJ}$ ethanol ( $\mathrm{gCO} 2 \mathrm{eq} / \mathrm{MJ})$.

Tabel 1 RED waarden voor suikerbiet ethanol

\begin{tabular}{|l|l|l|}
\hline Suikerbiet & Typical (gCO2eq/MJ) & Default (gCO2eq/MJ) \\
\hline Teelt & 9.6 & 9.6 \\
\hline Proces & 18.8 & 26.3 \\
\hline Transport (- distributie) & 0.7 & 0.7 \\
\hline Totaal & $\mathbf{2 9 . 1}$ & $\mathbf{3 6 . 6}$ \\
\hline
\end{tabular}

Tabel 2 RED waarden voor mais ethanol

\begin{tabular}{|l|l|l|}
\hline Mais & Typical $(\mathrm{gCO} 2 \mathrm{eq} / \mathrm{MJ})$ & Default $(\mathrm{gCO} 2 \mathrm{eq} / \mathrm{MJ})$ \\
\hline Teelt & 25.5 & 25.5 \\
\hline Proces & 20.8 & 29.1 \\
\hline Transport (- distributie) & 0.6 & 0.6 \\
\hline Totaal & $\mathbf{4 6 . 9}$ & $\mathbf{5 5 . 2}$ \\
\hline
\end{tabular}

Aangezien gewasresten geschikt zijn om biogas van te maken is deze optie meegenomen in de RED, echter niet voor ieder gewas. Dit is wel gedaan voor suikerbieten ethanol (Tabel 3). De uitstoot van het proces wordt verminderd door het produceren van biogas (Tabel 2 \& Tabel 3), wat weer gebruikt kan worden in het proces. Biogas heeft - afhankelijk van de gebruikte grondstof - een lagere uitstoot van broeikasgassen (BKG) dan aardgas, waardoor dit dus een milieuvriendelijker alternatief is.

In de RED is niet duidelijk wat er met de reststromen uit de mais gedaan wordt. Het is dus onbekend of er ook meegenomen is dat er binnen de bio-ethanol uit mais productie ook biogas en veevoer gemaakt wordt. We gaan er in dit rapport wel van uit dat dit rekening houdt met de productie van DDGS omdat dit een standaard restproduct is bij de productie van ethanol uit maïs.

Tabel 3 RED waarden voor suikerbiet ethanol met biogas productie

\begin{tabular}{|l|l|l|}
\hline Suikerbiet met biogas & Typical (gCO2eq/MJ) & Default (gCO2eq/MJ) \\
\hline Teelt & 9.6 & 9.6 \\
\hline Proces & 9.7 & 13.6 \\
\hline Transport (- distributie) & 0.7 & 0.7 \\
\hline Totaal & $\mathbf{2 0}$ & $\mathbf{2 3 . 9}$ \\
\hline
\end{tabular}


Het productieconcept zoals beschreven in de paragrafen 2.1, 2.2 en 2.3 zal vergeleken worden met bovenstaande RED waarden waarbij voor suikerbieten de RED-waarde wordt gebruikt die rekening houdt met de productie van biogas (Tabel 3). 


\section{Het model}

Een rekenmodel is opgezet om de broeikasgasemissie van de ethanol productie volgens het beschreven concept vast te stellen. Dit model wordt in deze paragraaf uitgewerkt. In dit model zijn de teelt, het productieproces van ethanol en het transport van de materialen meegenomen. Als output worden de CO2equivalenten van zowel teelt, verwerking als transport gebruikt. Daarnaast natuurlijk de hoeveelheid geproduceerd ethanol. En er wordt rekening gehouden met reststromen.

\subsection{Aannames}

Het model dat gebruikt is voor dit rapport, is gebaseerd op Europees vastgestelde berekeningsmethoden uit de Renewable Energy Directive (EU, 2018). Voor deze specifieke toepassing zijn de belangrijkste emissiefactoren meegenomen, maar bepaalde factoren blijven buiten beschouwing omdat deze niet relevant zijn voor dit project. Dat geldt vooral voor de emissiefactor "landuse change" (LUC). In dit model wordt ervan uit gegaan dat voor de productie van ethanol uit suikerbiet en snijmaïs geen nieuw akkerland wordt gecreëerd. Zodoende wordt er voor het berekenen van de duurzaamheidscore geen rekening gehouden met de hiermee geassocieerde milieubelasting (Woltjer et al., 2017). Hiervoor is gekozen aangezien uit wordt gegaan van kleinschalige en beperkte omzetting van suikerbieten (en snijmaïs) naar bio-ethanol. Bovendien is er voldoende ruimte in de akkerbouw rotatie in Nederland waar tegenwoordig 80.000 ha suikerbiet wordt geteeld tegen 135.000 in 1975 (cijfers CBS).

Qua emissies is er gekeken naar de CO2, N2O en CH4 emissies, andere emissies zoals NO2, NO3 en $\mathrm{NH} 3$ zijn, eveneens als in de RED, niet meegenomen.

Zoals beschreven in hoofdstuk 2.4 kan de uitstoot voor het produceren van bio-ethanol lager worden wanneer er ook nog andere producten in hetzelfde proces worden gevormd (rest- of zijstromen). Een deel van de uitstoot wordt dan toegeschreven aan deze reststromen in plaats van aan de bio-ethanol wanneer deze stromen een economische functie vervullen hetgeen het geval is met het gebruik van reststromen voor de productie van energie of veevoedergrondstoffen. Dit wordt alloceren genoemd. De allocatiefactor is in dit rapport gebaseerd op de lower heating value (LHV) van de producten (hoofdstroom en reststroom).

De gebruikte grondstoffen voor verwerking tot ethanol worden lokaal geproduceerd, rondom de ethanolfabriek. De hoeveelheid te verwerken materiaal komt dus uit een gebied met een te berekenen straal op basis van een aantal parameters waaronder de productiecapaciteit van de fabriek.

Het model is gebaseerd op een serie parameters waarvan sommigen variabel zijn en dus deel uitmaken van de gevoeligheidsanalyse. Andere parameters zijn niet gevarieerd en hebben dus een vaste waarde. Daarnaast maakt het model gebruik van een aantal aannames die hieronder staan benoemd.

De gebruikte waarden voor van N-kunstmest, P-kunstmest, K-kunstmest, herbicide, fungicide, insecticide en diesel voor de teelt van suikerbieten en snijmaïs zijn genomen van de KWIN cijfers voor Flevoland. Het gebruik van deze inputs verschilt van regio tot regio en dat zal tot kleine verschillen kunnen leiden, maar regioverschillen in de teelt zijn niet de focus van deze studie.

Snijmais bestaat uit meerdere te oogsten componenten, korrels, stengel, blad en spil. In dit rapport is de opbrengst gedefinieerd als de hoeveelheid korrel, in tonnen per hectare.

De energie die gemoeid is met de opslag van suikerbieten is gelijk gesteld aan die van de aardappel bewaring. De aanname is dat de oogst zich uitstrekt over een periode van 3 maanden (half september tot half december), dus 90 dagen. En dat daarna een periode volgt waarin suikerbieten in een luchtgekoelde bewaarplaats worden opgeslagen ten behoeve van de verwerking. De uiteindelijke 
periode waarin dat gebeurt is een variabele in het model. Onnodig te zeggen dat een langere periode bietenverwerking een kortere periode maïsverwerking vraagt (en omgekeerd).

De dichtheid van een suikerbieten lichaam is $1100 \mathrm{~kg} / \mathrm{m} 3$, hetgeen bepaald is door de waterverplaatsing en massa van een suikerbiet te meten (data niet weergegeven). De aanname is gemaakt dat de dichtheid van de suikerbietenmoes niet verandert ten opzichte van die van het suikerbietenlichaam. Daarnaast wordt er vanuit gegaan dat het volume dat de massa suikerbieten inneemt in de fermentoren even groot is als het volume dat de snijmais korrels innemen in de fermentoren. De hoeveelheid en formaat van de specifieke fermentoren is hierdoor niet relevant, alleen de fermentatie capaciteit.

Aangezien beide processen nog niet op grote schaal zijn uitgevoerd zijn er aannames gemaakt mbt de BKG emissie van het proces. Voor het suikerbietenproces (wassen tot aan destilatie), zoals beschreven in paragraaf 2.2 Direct processing is door het bedrijf TechnipFMC in opdracht van DSD een doorrekening gemaakt (zie Bijlage 1 Energieberekeningen ). Het stroom en stoom gebruik van het proces zoals in Bijlage 1 is aangegeven, is gebruikt binnen het model. Onderstaand de eindgegevens vanuit TechnipFMC rapport:

\section{Tabel 4 Utility consumptie van de suikerbiet verwerking}

\begin{tabular}{|l|l|l|}
\hline Stroom & 1860 & $\mathrm{kWh} / 83$ ton suikerbiet \\
\hline Stoom & 35548 & $\mathrm{~kg} / 83$ ton suikerbiet \\
\hline
\end{tabular}

Voor snijmais is hetzelfde gedaan. Echter zijn deze waarden gebaseerd op Liska et al., 2009. De berekening van deze waarden is te vinden in Bijlage 2.

\section{Tabel 5 Utility consumptie van de snijmais verwerking}

\section{Uitstoot $234.9 \quad \mathrm{gCO} e q / \mathrm{kg}$ snijmais}

Door Liska (et al., 2009) wordt niet vermeld welk type mais en bijbehorende droge stof \& zetmeel gehaltes gebruikt worden. Er is daarom aangenomen dat deze waarden vergelijkbaar zijn met die in dit rapport (zie volgende paragrafen).

\subsection{Parameters}

Verder zijn er nog andere parameterwaarden nodig binnen het model. In onderstaande tabel is een overzicht te vinden van waarden die niet gerefereerd zijn.

Tabel 6 Niet gerefeerde parameters

\begin{tabular}{|l|l|l|l|l|}
\hline Modelterm & Wat & Waarde & \multicolumn{1}{|l|}{ Eenheid } & Opmerkingen \\
\hline Suikerbiet.water.ton & $\begin{array}{l}\text { Hoeveelheid water } \\
\text { toe te voegen aan } \\
\text { de suikerbieten in } \\
\text { de reactor }\end{array}$ & 0 & Ton/ton & \\
\hline Efficiency.starch.proces & $\begin{array}{l}\text { Omzetting } \\
\text { efficiëntie van } \\
\text { zetmeel naar } \\
\text { suiker }\end{array}$ & 0.90 & - & \\
\hline Max.etOH & $\begin{array}{l}\text { Maximale ethanol } \\
\text { fractie (volume) }\end{array}$ & 0.14 & - & Hierbij sterft het gist \\
\hline Suikerbiet.dichtheid & $\begin{array}{l}\text { Dichtheid } \\
\text { suikerbieten na } \\
\text { vermoezing }\end{array}$ & 1100 & $\mathrm{Kg} / \mathrm{m3}$ & Zie paragraaf 3.1 \\
\hline
\end{tabular}




\begin{tabular}{|c|c|c|c|c|}
\hline Snijmais.dichtheid & $\begin{array}{l}\text { Dichtheid } \\
\text { snijmaiskorrels }\end{array}$ & 710 & $\mathrm{Kg} / \mathrm{m} 3$ & $\begin{array}{l}\text { Gebaseerd op het } \\
\text { hectolitergewicht, te } \\
\text { vinden op Wikipedia }\end{array}$ \\
\hline Suikerbiet.rotatie & $\begin{array}{l}\text { Rotatie van de } \\
\text { suikerbiet in het } \\
\text { bouwplan in het } \\
\text { gebied }\end{array}$ & 4 & Year & $\begin{array}{l}\text { In de praktijk } \\
\text { gebruikelijke } \\
\text { rotatiewaarde }\end{array}$ \\
\hline Snijmais.rotatie & $\begin{array}{l}\text { Rotatie van de } \\
\text { snijmais in het } \\
\text { bouwplan in het } \\
\text { gebied }\end{array}$ & 1 & Year & $\begin{array}{l}\text { Snijmaïs wordt in de } \\
\text { praktijk vaak continu } \\
\text { geteeld. }\end{array}$ \\
\hline Snijmais.tarra & $\begin{array}{l}\text { Percentage tarra } \\
\text { aan het } 2^{\mathrm{e}} \text { gewas }\end{array}$ & 0 & $\%$ & \\
\hline Onderhoud.dagen.fabriek & $\begin{array}{l}\text { Aantal dagen dat } \\
\text { de fabriek niet } \\
\text { gebruikt kan } \\
\text { worden }\end{array}$ & 55 & $\begin{array}{l}\text { Days/ } \\
\text { year }\end{array}$ & $\begin{array}{l}\text { Nodig voor uitvoeren } \\
\text { van onderhoud aan } \\
\text { de fabriek } \\
\text { (Inschatting Hans van } \\
\text { Klink (pers. med.)) }\end{array}$ \\
\hline Afstand.E10 & $\begin{array}{l}\text { Afstand tussen de } \\
\text { etOH fabriek en de } \\
\text { E10 fabriek }\end{array}$ & 100 & $\mathrm{~km}$ & \\
\hline Efficiency.steam & $\begin{array}{l}\text { Efficiëntie stoom } \\
\text { productie vanuit } \\
\text { aardgas }\end{array}$ & 85 & $\%$ & $\begin{array}{l}\text { Ervaringen Carel } \\
\text { Braakman (pers. } \\
\text { med.) }\end{array}$ \\
\hline Snijmais.CO2.kg & $\begin{array}{l}\text { CO2 equivalenten } \\
\text { gekoppeld aan de } \\
\text { verwerking van } 1 \\
\text { kg snijmais }\end{array}$ & 234.9 & $\begin{array}{l}\text { gCO2eq/ } \\
\text { kg } \\
\text { snijmais }\end{array}$ & Zie paragraaf 3.1 \\
\hline
\end{tabular}

Een aantal waarden die gebruikt wordt in het model zijn gebaseerd op referenties. In onderstaande tabel zijn deze waarden weergegeven. Een aantal van deze waarden zou in theorie ook variabel kunnen zijn, zoals het droge stof gehalte van de suikerbiet. Echter is ervoor gekozen de invloed van deze parameters op de einduitkomst niet uit te rekenen en daarmee als vaste waarde op te nemen.

Tabel 7 Gerefereerde parameters

\begin{tabular}{|c|c|c|c|c|}
\hline Modelterm & Wat & Waarde & $\begin{array}{l}\text { Eenhei } \\
\text { d }\end{array}$ & Bron \\
\hline DS.suikerbiet & $\begin{array}{l}\text { Drogestofgehalte } \\
\text { suikerbiet }\end{array}$ & 25 & $\%$ & $\begin{array}{l}\text { Sorgedrager \& de } \\
\text { Koning, } 2019\end{array}$ \\
\hline Suikerbiet.ODS & $\begin{array}{l}\text { Hoeveelheid } \\
\text { organische stof van } \\
\text { de droge stof }\end{array}$ & 0.96 & - & $\begin{array}{l}\text { De Visser \& Spruijt, } \\
2013\end{array}$ \\
\hline Suikerbiet.CH4 & $\begin{array}{l}\text { Hoeveelheid } \mathrm{CH} 4 \\
\text { te krijgen uit } 1 \text { ton } \\
\text { ODS }\end{array}$ & 275 & $\begin{array}{l}\mathrm{m}^{3} / \text { ton } \\
\text { ODS }\end{array}$ & $\begin{array}{l}\text { De Visser \& Spruijt, } \\
2013\end{array}$ \\
\hline Suikerbiet.energie.opslag & $\begin{array}{l}\text { Energieverbruik } \\
\text { opslag suikerbieten }\end{array}$ & 0.073 & $\begin{array}{l}\text { kWh / } \\
\text { ton / } \\
\text { day }\end{array}$ & $\begin{array}{l}\text { Kamp \& Montsma, } \\
2013\end{array}$ \\
\hline Suikerbiet.procestime & $\begin{array}{l}\text { Procestijd } \\
\text { suikerbieten }\end{array}$ & 36 & h & $\begin{array}{l}\text { Sorgedrager \& de } \\
\text { Koning, } 2019\end{array}$ \\
\hline DS.snijmais & $\begin{array}{l}\text { Drogestofgehalte } \\
\text { snijmais korrel }\end{array}$ & 70 & $\%$ & $\begin{array}{l}\text { Schipperus \& Spruijt, } \\
2013\end{array}$ \\
\hline Snijmais.ODS & $\begin{array}{l}\text { Hoeveelheid } \\
\text { organische stof van } \\
\text { de droge stof }\end{array}$ & 0.96 & - & $\begin{array}{l}\text { De Visser \& Spruijt, } \\
2013\end{array}$ \\
\hline
\end{tabular}




\begin{tabular}{|c|c|c|c|c|}
\hline Snijmais.CH4 & $\begin{array}{l}\text { Hoeveelheid } \mathrm{CH} 4 \\
\text { te krijgen uit } 1 \text { ton } \\
\text { ODS }\end{array}$ & 275 & $\begin{array}{l}\mathrm{m}^{3} / \text { ton } \\
\text { ODS }\end{array}$ & $\begin{array}{l}\text { De Visser \& Spruijt, } \\
2013\end{array}$ \\
\hline Snijmais.percentage.korrel & $\begin{array}{l}\text { fractie korrel in de } \\
\text { snijmais (van DS) }\end{array}$ & 0.545 & - & $\begin{array}{l}\text { Persoonlijke } \\
\text { mededeling JAM (Jos) } \\
\text { Groten }\end{array}$ \\
\hline Snijmais.percentage.stro & $\begin{array}{l}\text { fractie stro van de } \\
\text { snijmais (van DS) }\end{array}$ & 0.455 & - & $\begin{array}{l}\text { Persoonlijke } \\
\text { mededeling JAM (Jos) } \\
\text { Groten }\end{array}$ \\
\hline $\begin{array}{l}\text { Snijmais.percentage.eiwit.kor } \\
\text { rel }\end{array}$ & $\begin{array}{l}\text { Percentage eiwit } \\
\text { binnen de korrel } \\
\text { van snijmais (van } \\
\text { DS) }\end{array}$ & 10 & $\%$ & $\begin{array}{l}\text { Persoonlijke } \\
\text { mededeling JAM (Jos) } \\
\text { Groten }\end{array}$ \\
\hline Snijmais.stro & $\begin{array}{l}\text { Hoeveelheid stro } \\
\text { per hectare }\end{array}$ & 7500 & $\begin{array}{l}\mathrm{Kg} \mathrm{DS} / \\
\text { ha }\end{array}$ & $\begin{array}{l}\text { Persoonlijke } \\
\text { mededeling JAM (Jos) } \\
\text { Groten }\end{array}$ \\
\hline Snijmais.procestime & $\begin{array}{l}\text { Fermentatietijd } \\
\text { snijmais }\end{array}$ & 48 & $\mathrm{~h}$ & $\begin{array}{l}\text { Gebasseerd op } \\
\text { Schipperus \& Spruijt, } \\
2013\end{array}$ \\
\hline Dichtheid.etOH & Dichtheid ethanol & 785.3 & $\mathrm{~kg} / \mathrm{m}^{3}$ & $\begin{array}{l}\text { Engineeringtoolbox.co } \\
\mathrm{m} \text { Ethanol }\end{array}$ \\
\hline $\begin{array}{l}\text { Theoretische.yield.etOH.sucro } \\
\text { se }\end{array}$ & $\begin{array}{l}\text { Theoretische } \\
\text { opbrengst ethanol } \\
\text { uit sucrose }\end{array}$ & 0.538 & $\mathrm{~kg} / \mathrm{kg}$ & Kootstra, 2017 \\
\hline $\begin{array}{l}\text { Theoretische.yield.etOH.gluco } \\
\text { se }\end{array}$ & $\begin{array}{l}\text { Theoretische } \\
\text { opbrengst ethanol } \\
\text { uit glucose \& } \\
\text { fructose } \\
\text { (afbraakproducten } \\
\text { van zetmeel) }\end{array}$ & 0.511 & $\mathrm{~kg} / \mathrm{kg}$ & Kootstra, 2017 \\
\hline MJ.ton.etOH & $\begin{array}{l}\text { Energie inhoud } \\
\text { ethanol }\end{array}$ & 29017 & $\mathrm{MJ} /$ ton & $\begin{array}{l}\text { Engineeringtoolbox.co } \\
\mathrm{m} \text { Ethanol }\end{array}$ \\
\hline Truck.uitstoot & $\begin{array}{l}\text { CO2 equivalenten } \\
\text { per km voor een } \\
\text { truck per ton } \\
\text { gewicht (voertuig } \\
+ \text { lading) }\end{array}$ & 110 & $\begin{array}{l}\text { gCO2eq } \\
\text { /tonkm }\end{array}$ & Otten et al., 2017 \\
\hline Truck.gewicht.leeg & $\begin{array}{l}\text { Gewicht van een } \\
\text { volle vrachtwagen }\end{array}$ & 46 & Ton & Otten et al., 2017 \\
\hline Truck.gewicht.vol & $\begin{array}{l}\text { Gewicht van een } \\
\text { lege vrachtwagen }\end{array}$ & 18 & Ton & Otten et al., 2017 \\
\hline $\mathrm{CH} 4 . \mathrm{CO} 2 \mathrm{eq}$ & $\begin{array}{l}\mathrm{CO} 2 \text { equivalenten } \\
\text { per gram } \mathrm{CH} 4\end{array}$ & 25 & $\begin{array}{l}\mathrm{gCO} 2 / \\
\mathrm{g}\end{array}$ & Eggleston et al., 2006 \\
\hline N2O.CO2eq & $\begin{array}{l}\mathrm{CO} 2 \text { equivalenten } \\
\text { per gram } \mathrm{N} 2 \mathrm{O}\end{array}$ & 298 & $\begin{array}{l}\mathrm{gCO} 2 / \\
\mathrm{g}\end{array}$ & Eggleston et al., 2006 \\
\hline Stroom.CO2eq & $\begin{array}{l}\mathrm{CO} 2 \text { equivalenten } \\
\text { voor stroom } \\
\text { productie }\end{array}$ & 475 & $\begin{array}{l}\mathrm{gCO} 2 / \\
\mathrm{kWh}\end{array}$ & $\begin{array}{l}\text { Milieucentraal \& } \\
\text { Stimular, } 2020\end{array}$ \\
\hline Aardgas.CO2eq & $\begin{array}{l}\mathrm{CO} 2 \text { equivalenten } \\
\text { voor aardgas } \\
\text { verbranding }\end{array}$ & 1785 & $\begin{array}{l}\mathrm{gCO} 2 / \\
\mathrm{nm}^{3}\end{array}$ & $\begin{array}{l}\text { Milieucentraal \& } \\
\text { Stimular, } 2020\end{array}$ \\
\hline MJ.ton.stoom & $\begin{array}{l}\text { Energie inhoud } \\
\text { stoom }\end{array}$ & 2676 & $\mathrm{MJ} /$ ton & $\begin{array}{l}\text { Engineeringtoolbox.co } \\
\text { m Steam }\end{array}$ \\
\hline MJ.nm3.aardgas & $\begin{array}{l}\text { Energie inhoud } \\
\text { aardgas }\end{array}$ & 35.17 & $\begin{array}{l}\mathrm{MJ} / \\
\mathrm{nm} 3\end{array}$ & Dueck et al., 2004 \\
\hline
\end{tabular}




\begin{tabular}{|c|c|c|c|c|}
\hline Water.dichtheid & Dichtheid water & 997 & $\mathrm{Kg} / \mathrm{m} 3$ & $\begin{array}{l}\text { Engineeringtoolbox.co } \\
\mathrm{m} \text { Water }\end{array}$ \\
\hline LHV.etOH & $\begin{array}{l}\text { Lower heating } \\
\text { value ethanol }\end{array}$ & 26.81 & $\mathrm{MJ} / \mathrm{kg}$ & Edwards et al., 2017 \\
\hline LHV.SBpulp & $\begin{array}{l}\text { Lower heating } \\
\text { value suikerbieten } \\
\text { pulp (droog) }\end{array}$ & 16.1 & $\mathrm{MJ} / \mathrm{kg}$ & $\begin{array}{l}\text { Kaltschmitt \& } \\
\text { Reinhardt, } 1997\end{array}$ \\
\hline LHV.DDGS & $\begin{array}{l}\text { Lower heating } \\
\text { value Distiller`s } \\
\text { Dried Grains with } \\
\text { Solubles }\end{array}$ & 18.13 & $\mathrm{MJ} / \mathrm{kg}$ & Edwards et al., 2017 \\
\hline LHV.snijmaiskorrel & $\begin{array}{l}\text { Lower heating } \\
\text { value snijmais } \\
\text { korrels }\end{array}$ & 17.01 & $\mathrm{MJ} / \mathrm{kg}$ & Lizotte et al., 2015 \\
\hline LHV.snijmaisresten & $\begin{array}{l}\text { Lower heating } \\
\text { value snijmais } \\
\text { resten (plant } \\
\text { materiaal) }\end{array}$ & 17.41 & $\mathrm{MJ} / \mathrm{kg}$ & Lizotte et al., 2015 \\
\hline Diesel.dichtheid & Dichtheid diesel & 832 & $\mathrm{Kg} / \mathrm{m}^{3}$ & Kootstra, 2018 \\
\hline
\end{tabular}

De teeltbenodigdheden, zoals meststoffen, gewasbeschermingsmiddelen en diesel hebben gaan allemaal gepaard met BKG emissie. In Tabel 8 worden ze opgesomd.

Tabel 8 Energie verbruik \& uitstoot teeltbenodigdheden.

\begin{tabular}{|c|c|c|c|c|}
\hline & $\mathrm{kg} \mathrm{CO2} \mathrm{/} \mathrm{kg}$ & kg CH4 / kg & kg N20 / kg & \\
\hline N-kunstmest & 1.904 & $3.6 * 10^{\wedge}-3$ & 0.0183 & Mortimer et al., 2003 \\
\hline P-kunstmest & 0.7 & $2.3^{*} 10^{\wedge}-5$ & $4.2 * 10^{\wedge}-5$ & $\begin{array}{l}\text { Beer et al., } 2001 \text { \& } \\
\text { Kaltschmitt \& Reinhardt } 1997\end{array}$ \\
\hline K-kunstmest & 0.453 & $2.1 * 10^{\wedge}-5$ & $9.4^{*} 10^{\wedge}-6$ & $\begin{array}{l}\text { Beer et al., } 2001 \text { \& } \\
\text { Kaltschmitt \& Reinhardt } 1997\end{array}$ \\
\hline Herbicide & 4.921 & $1.8 * 10^{\wedge}-4$ & $1.51 * 10^{\wedge}-3$ & $\begin{array}{l}\text { Beer et al., } 2001 \text { \& } \\
\text { Kaltschmitt \& Reinhardt } 1997\end{array}$ \\
\hline Fungicide & 4.921 & $1.8^{*} 10^{\wedge}-4$ & $1.51 * 10^{\wedge}-3$ & $\begin{array}{l}\text { Beer et al., } 2001 \text { \& } \\
\text { Kaltschmitt \& Reinhardt } 1997\end{array}$ \\
\hline Insecticide & 4.921 & $1.8 * 10^{\wedge}-4$ & $1.51 * 10^{\wedge}-3$ & $\begin{array}{l}\text { Beer et al., } 2001 \text { \& } \\
\text { Kaltschmitt \& Reinhardt } 1997\end{array}$ \\
\hline Diesel & 0.0767 & $2.1 * 10^{\wedge}-5$ & $5.9 * 10^{\wedge}-7$ & Howard et al, 1999 \\
\hline
\end{tabular}

Een aantal van de inputs uit Tabel 8 dat in de teelt van suikerbieten en snijmaïs gebruikt wordt is afhankelijk van het gebied. Welke van de inputs nodig zijn in een bepaalde teelt, zijn te vinden in de KWIN-AGV (2018). In Tabel 9 zijn de benodigde inputs van beide gewassen voor teelt in Flevoland opgenomen.

Tabel 9 Gemiddelde teeltbenodigdheden voor Flevoland per hectare (KWIN, 2018)

\begin{tabular}{|c|c|c|c|c|c|c|c|}
\hline & $\begin{array}{l}\text { Diesel } \\
\text { (I) }\end{array}$ & $\begin{array}{l}\text { N- } \\
\text { kunstmest } \\
\text { (kg) }\end{array}$ & $\begin{array}{l}\text { P- } \\
\text { kunstmest } \\
\text { (kg) }\end{array}$ & $\begin{array}{l}\text { K- } \\
\text { kunstmest } \\
\text { (kg) }\end{array}$ & $\begin{array}{l}\text { Herbicide } \\
\text { (kg) }\end{array}$ & $\begin{array}{l}\text { Fungicide } \\
\text { (kg) }\end{array}$ & $\begin{array}{l}\text { Insecticide } \\
\text { (kg) }\end{array}$ \\
\hline Suikerbiet & 122 & 150 & 60 & 50 & 10.5 & 2 & 2 \\
\hline Snijmais & 72 & 160 & 60 & 0 & 3.1 & 0 & 0 \\
\hline
\end{tabular}

Wanneer het suikerpercentage van het gewas niet bekend is maar wel het zetmeel percentage, zoals bij snijmais, wordt omgerekend hoeveel suiker er uit dit zetmeel gemaakt kan worden. Aangezien deze omzetting waarschijnlijk niet perfect verloopt (100\% omzetting) is er een parameter meegenomen in vergelijking 1 die deze efficiëntie bepaalt (efficiency.starch.proces, zie Tabel 6). 
Daarnaast is de suiker die uit zetmeel komt (glucose) niet dezelfde als die uit suikerbieten komt (sucrose). De ethanol opbrengst per ton is afhankelijk van het type suiker. Hiermee wordt in vergelijking 12 rekening gehouden met de parameters theoretisch.yield.etOH.glucose en theoretisch.yield.etOH.sucrose (zie Tabel 7).

\subsection{Variabelen}

Bovenstaande parameters zijn niet gevarieerd in onze analyse van de resultaten. Een aantal waarden is echter wél gevarieerd omdat verwacht wordt dat zij een belangrijke invloed hebben op het resultaat of omdat het belangrijke keuzes zijn in de opzet van het proces. Per variabele wordt het effect van een variatie van $-10 \%$ en $+10 \%$ op de einduitkomst bepaald. Op deze -bandbreedte zijn drie uitzonderingen: de efficiëntie van de omzetting van suiker naar ethanol, het percentage akkerbouw in het sourcingsgebied voor de fabriek en het suikerbiet tarra percentage zijn gevarieerd met stappen van 5 procentpunt. Bijvoorbeeld: voor het percentage akkerbouw in het doelgebied van de fabriek resulteert dit in: $20 \%, 25 \%$ en $30 \%$ van de oppervlakte.

De standaardwaarde wordt in elke berekening gebruikt, behalve wanneer deze specifieke variabele gevarieerd wordt.

Tabel 10 Variabele inputs per scenario

\begin{tabular}{|c|c|c|c|}
\hline \multicolumn{2}{|l|}{ Variabele } & \multirow{2}{*}{$\begin{array}{l}\text { eenheid } \\
\%\end{array}$} & \multirow{2}{*}{$\begin{array}{l}\text { Standaardwaarde } \\
25\end{array}$} \\
\hline Percentage.akkerbouw & $\begin{array}{l}\text { Percentage } \\
\text { akkerbouw in het } \\
\text { gebied }\end{array}$ & & \\
\hline Suikerbiet.opbrengst & Gewasopbrengst & Ton / ha & 94.5 \\
\hline Suikerbiet.suiker.percentage & $\begin{array}{l}\text { Percentage suiker in } \\
\text { suikerbiet }\end{array}$ & $\%$ & 17.5 \\
\hline Suikerbiet.tarra & $\begin{array}{l}\text { Percentage tarra aan } \\
\text { suikerbiet }\end{array}$ & $\%$ & 10 \\
\hline Suikerbiet.fabrieks.capaciteit & $\begin{array}{l}\text { Fabrieks capaciteit } \\
\text { voor suikerbiet }\end{array}$ & Ton / day & 2200 \\
\hline Suikerbiet.verwerkingsdagen & $\begin{array}{l}\text { Aantal } \\
\text { verwerkingsdagen } \\
\text { voor gewas1 per jaar }\end{array}$ & Days / year & 200 \\
\hline Snijmais.opbrengst & $\begin{array}{l}\text { Opbrengst gewas } \\
\text { (korrel) }\end{array}$ & Ton / ha & 9 \\
\hline Snijmais.suiker.percentage & $\begin{array}{l}\text { Percentage suiker in } \\
\text { het } 2^{\mathrm{e}} \text { gewas }\end{array}$ & $\%$ & 80 \\
\hline $\begin{array}{l}\text { Efficiency.etOH.proces (van de } \\
\text { fabriek) }\end{array}$ & $\begin{array}{l}\text { Omzetting efficiëntie } \\
\text { van suikers naar } \\
\text { ethanol }\end{array}$ & $\%$ & 90 \\
\hline
\end{tabular}

Daarnaast zijn het stoom en stroom gebruik tijdens het verwerkingsproces van de suikerbieten gevarieerd met $-20 \%,-10 \%$ en $+10 \%$.

\subsection{De formules}

Onderstaand een uitwerking van alle berekeningen die gebruikt worden om te bepalen wat de BKG emissie van de ethanol productie is. 


\subsubsection{Grondstof gerelateerde berekeningen}

Wanneer snijmais gebruikt wordt is er sprake van zetmeel, dit zetmeel moet eerst omgezet worden in suiker. Met onderstaande formule kan berekend worden hoeveel suiker er uit een kg zetmeel komt:

zetmeel.suiker $=180 / 162 *$ efficiency. starch.proces $[\mathrm{kg}$. suiker $/ \mathrm{kg} . \mathrm{zetmeel}]$

Het aantal dagen dat snijmais verwerkt kan worden is te berekenen aan de hand van hoeveel dagen suikerbiet verwerkt wordt.

snijmais.verwerkingsdagen $=365$ - Onderhoud.dagen.fabriek - suikerbiet.verwerkingsdagen [day][2]

Om te berekenen wat de fabriekscapaciteit is voor snijmais, is gewerkt met de dichtheid en capaciteit van suikerbiet. Immers, het gewicht van de gewassen in de tank verandert doordat snijmais een andere dichtheid heeft, het volume wat in de tank past blijft hetzelfde (zie hoofdstuk 3.1 Aannames). Om te beginnen is berekend voor de suikerbieten welk volume de suikerbieten in de fermentoren inneemt. Hiervoor moet ook rekening gehouden worden met het eventueel toevoegen van water tijdens het proces:

inhoud.tank = suikerbiet. fabrieks.capaciteit.dag *1000/suikerbiet.dichtheid + suikerbiet. water.ton * suikerbiet. fabrieks. capaciteit.dag*1000/water. dichtheid [m3 / day]

Om vervolgens de fabriekscapaciteit voor de snijmais te bereken is bovenstaande formule omgeschreven. Zoals aangegeven verandert het volume van de massa in de fermentor niet bij wisseling tussen suikerbiet en snijmais. Echter, er is wel een verschil in tijdsduur van het proces, dit is meegenomen in de laatste term van vergelijking 9. Bij fermentatie van snijmaïs wordt water toegevoegd om de ethanolconcentratie niet te hoog te maken i.v.m. afsterven van het gist. De hoeveelheid water toe te voegen per ton snijmais is te berekenen met een aantal stappen. De hoeveelheid ethanol (liters) geproduceerd per ton snijmais:

etOH.l.ton $=$ DS. snijmais $*$ snijmais.percentage.suiker $/ 100 *$ zetmeel.suiker $*$ efficiency.proces $*$ theoretische.yield.etOH.glucose/(etOH.dichtheid/1000000) [l etOH / ton snijmais ]

De hoeveelheid ethanol (liters) geproduceerd per liter snijmais:

etOH.l.l = etOH.l.ton /1000/ (1 / (snijmais. dichtheid /1000)) [l etOH / l snijmais $]$

Wanneer dit hoger is dan het gekozen maximum moet er verdund worden. De hoeveelheid water die per liter snijmais toegevoegd moet worden:

water.l.l = etOH.l.l/max.etOH $-1-$ etOH.l.l [l water / l snijmais $]$

De hoeveelheid water (ton) dit is per ton snijmais:

water.ton $=$ water.l.l / $1000 *$ water. dichtheid $/ 1000 /(1 / 1000 *$ snijmais. dichtheid $/ 1000)[$ ton water / ton snijmais]

Hiermee kan de hoeveelheid snijmais in de fermentor berekend worden:

snijmais.ton $=$ inhoud.tank $/($ water. ton $/$ water. dichtheid $+1 /$ snijmais. dichtheid $)[$ ton $]$

En daaruit de capaciteit per dag:

snijmais.fabrieks. capaciteit.dag = snijmais.ton $*$ suikerbiet.procestime/suikerbiet.procestime [ton/day]

Deze capaciteit per dag wordt verder gebruikt in het model. 


\subsubsection{Algemene berekeningen per gewas}

Door bovenstaande stappen zijn alle inputs voor suikerbieten en snijmais bekend. Hierdoor kunnen de volgende meer algemene zaken per gewas uitgerekend worden, een deel van de berekende waarden zal terugkomen in andere berekeningen.

De benodigde hoeveelheid van het gewas:

benodigde.hoeveelheid $=$ fabrieks.capaciteit $*$ verwerkings.dagen $[$ ton $/ y]$

Hoeveel suiker dit is:

hoeveelheid.suiker $=$ benodigde. hoeveelheid $*$ percentage. suiker $/ 100$ [ton]

Hoeveel ethanol hieruit komt, wordt berekend in [12]:

hoeveelheid.etOH.ton $=$ hoeveelheid. suiker $*$ theoretische. yield. etOH. "suikerbron" $*$ efficiency.proces / $100[$ ton]

Waarbij de suikerbron zowel glucose als sucrose kan zijn, dit is per gewas gedefinieerd (Tabel 7). Hoeveel ethanol dit is in MJ wordt berekend in [13] :

hoeveelheid.etOH.MJ = hoeveelheid.etOH.ton $*$ MJ.ton.etOH $[\mathrm{MJ}]$

Hoeveel hectare hiervoor nodig is:

areaal.gewas $=$ benodigde. hoeveelheid / opbrengst $[$ ha $]$

Hoeveel hectare landbouwgrond dit is, rekening houdend met goed grondgebruik (rotatie):

ha. akkerbouw $=$ areaal, gewas $*$ rotatie $[$ ha $]$

Hoe groot het gebied hiervoor moet zijn:

areaal.gebied $=$ ha.akkerbouw $/($ percentage.landbouw $/ 100)[$ ha $]$

Welke straal er nodig is rond de fabriek om dit gebied te verkrijgen:

straal $=\operatorname{sqrt}($ areaal. gebied $/ 100 / \pi)[\mathrm{km}]$

Wat de gemiddelde afstand is tot de etOH fabriek binnen dit gebied:

gemiddelde. afstand $=\operatorname{sqrt}\left(0.5 *\right.$ straal $\left.^{\wedge} 2\right)[\mathrm{km}]$

\subsubsection{Teelt uitstoot}

De hoeveelheid $\mathrm{CO} 2$ equivalenten voor de teelt per gewas, wordt berekend aan de hand van de uitstoot gekoppeld aan het gebruik van diesel, N-kunstmest, P-kunstmest, K-kunstmest, herbicide, fungicide en insecticide. De gemiddelde hoeveelheid die van deze inputs is ontleend aan de KWIN (zie Tabel 9). De BKG emissies die daarbij horen staan opgenomen in Tabel 8. Voor zowel de CO2, N2O als $\mathrm{CH} 4$ uitstoot geldt de volgende formule:

totale.uitstoot. ha $=$ diesel.ha $*$ diesel.uitstoot $*$ diesel.dichtheid + Nkunstmest.ha $*$ Nkunstmest. uitstoot + Pkunstmest.ha* Pkunstmest.uitstoot + Kkunstmest.ha $*$ Kkunstmest.uitstoot + herbicide. ha $*$ herbicide.uitstoot + fungicide.ha $*$ fungicide.uitstoot + insecticide.ha $*$ insecticide.uitstoot $[\mathrm{g} / \mathrm{ha}]$

Om tot de totale hoeveelheid CO2equivalenten per hectare te komen moeten deze gewogen opgeteld worden: 
CO2eq. ha $=$ totale.uitstoot.CO2.ha + totale.uitsoot.N2O.ha*N2O.CO2eq + totale. uitstoot.CH4.ha*

Bij snijmais wordt al op het veld een scheiding gemaakt tussen korrel en restmateriaal. Hierdoor wordt niet alles van het gewas gebruikt voor de ethanol productie. De stengel en blad worden gebruikt als grondstof voor de productie van biogas op basis van vergisting. De COzequivalenten die toegeschreven kunnen worden aan de teelt component van de bio-ethanol zijn daardoor anders. Hiervoor is een zogeheten allocatiefactor nodig. Deze is niet nodig bij de suikerbieten teelt. De allocatiefactor voor de snijmais teelt is te berekenen met:

allocatiefactor. snijmais.teelt $=($ LHV. (snijmais. korrel $) *$ snijmais.korrel.stro $) /($ LHV. $($ snijmais. korrel $) *$ snijmais. korrel.stro + LHV. (snijmais.resten $) *(1-$ snijmais. korrel.stro $))$

waarin snijmais.korrel.stro de fractie korrel ten opzichte van totaal van het drooggewicht is. Hiermee kan de totale $\mathrm{CO} 2$ equivalenten uitstoot voor de teelt berekend worden:

CO2eq. teelt $=$ CO2eq.ha $*$ areaal.gewas $*$ allocatiefactor $[g C O 2 e q]$

\subsubsection{Verwerking uitstoot}

De berekeningen van de uitstoot behorende tot de verwerking tot ethanol is per gewas gedaan. Voor de suikerbiet verwerking zijn de gegevens van TechnipFMC gebruikt (zie hoofdstuk 3.1 3.2Aannames).

CO2eq. tonSB. day = stroom. hoeveelheid $*$ stroom. uitstoot + stoom.hoeveelheid $*$ stoom. uitstoot $[\mathrm{gCO} e q$ / ton $]$

De uitstoot voor stoom is berekend aan de hand van de stoomproductie met behulp van aardgas:

stoom.uitstoot $=$ MJ.ton. stoom $/ 1000 /$ MJ.nm3.aardgas $*$ efficiency.steam $*$ aardgas.uitstoot $[\mathrm{gCO} 2 \mathrm{eq} / \mathrm{kg}]$

Allocatie m.b.t. het suikerbiet proces is gebaseerd op de lower heating values (LHV) van de suikerbieten pulp en die van ethanol, dit zijn de twee stromen die ontstaan.

allocatiefactor.SB.proces $=($ LHV.etOH $*$ hoeveelheid.etOH.ton $) /($ LHV.etOH $*$ hoeveelheid.etOH.ton + LHV.SBpulp * hoeveelheid.SBpulp $)[-]$

De hoeveelheid pulp is te berekenen met de volgende formule:

hoeveelheid.SBpulp = benodigde.hoeveelheid $*((D S . g e h a l t e-$ suiker.percentage $) / 100)$ [ton dry] [26]

Voor de snijmais verwerking zijn de gegevens van Liska (et al., 2009) gebruikt (zie hoofdstuk 3.1 3.2Aannames).

CO2eq. snijmais.proces $=$ Snijmais. CO2. $\mathrm{kg} * 1000 *$ benodigde. hoeveelheid $[\mathrm{gCO} 2 \mathrm{eq}]$

Voor het snijmais proces is een vergelijkbare allocatie formule te maken als voor suikerbiet (zie vergelijking 25), echter dient de pulp vervangen te worden door "maize dried distillers grains with solubles" (DDGS), het eiwitrijke restproduct wat achter blijft na een alcoholfermentatie van snijmais. Dit distillers grain is te gebruiken als veevoer. Aangezien hier het suiker percentage het percentage van de droge stof is, wordt de berekening iets anders:

hoeveelheid.DDGS = benodigde.hoeveelheid $*(1-$ suiker.percentage /100)[ton]

Hierdoor ziet de allocatiefactor berekening er als volgt uit: 
allocatiefactor. snijmais.proces $=(($ LHV.etOH $*$ hoeveelheid.etOH.ton $)) /($ LHV.etOH $*$ hoeveelheid.etOH.ton + LHV.snijmais. DDGS * hoeveelheid.DDGS $)[-]$

Naast het proces moeten de suikerbieten ook opgeslagen worden, de uitstoot gekoppeld aan de opslag is te berekenen met:

CO2eq. opslag $=0.5 *$ suikerbiet. verwerkingsdagen $-90 *$ benodigde.hoeveelheid $*$ energie.opslag $*$ stroom.uitstoot $[\mathrm{gCO} 2 \mathrm{eq}]$

De hoeveelheid $\mathrm{CO} 2$ equivalenten voor het proces:

CO2eq. proces $=$ CO2eq.tonSB. day $*$ suikerbiet. fabrieks. capaciteit $*$ suikerbiet. verwerkingsdagen $*$ allocatiefactor $[\mathrm{gCO} 2 \mathrm{eq}]$

\subsubsection{Transport uitstoot}

Wanneer de afstand van het gebied bekend is kan de uitstoot gekoppeld aan transport berekend worden met onderstaande formules, dit wordt per gewas gedaan:

Hoeveel lading een vrachtwagen kan vervoeren:

inhoud.vrachtwagen $=$ truck. gewicht.vol - truck. gewicht.leeg $[$ ton $]$

Hoeveel ton gewas er in een vrachtwagen kan:

hoeveelheid.in.vrachtwagen $=$ inhoud.vrachtwagen $*(100-$ tarra $) / 100[$ ton $]$

Hoeveel vrachten dit van het gewas zijn:

aantal.vrachten.gewas $=$ benodigde. hoeveelheid / hoeveelheid.in.vrachtwagen [-]

Aantal vrachten ethanol dit zijn:

aantal.vrachten.etOH $=$ hoeveelheid.etOH / inhoud.vrachtwagen $[-]$

De CO2 equivalenten die bij het vervoer van het gewas naar de fabriek horen:

C02eq. transport.gewas $=($ truck. gewicht.vol + truck. gewicht.leeg $) *$ truck. uitstoot $*$ aantal.vrachten.gewas $*$ gemiddelde. af stand $[\mathrm{gCO} 2 \mathrm{eq}]$

De CO2 equivalenten die bij het vervoer van ethanol naar de E10 fabriek horen:

CO2eq. transport.etOH $=($ truck.gewicht.vol + truck.gewicht.leeg $) *$ truck. uitstoot $*$ aantal.vrachten. etOH $*$ afstand.E10 [gCO2eq]

Totale hoeveelheid $\mathrm{CO} 2$ equivalenten voor transport:

CO2eq.transport $=$ CO2eq.transport.gewas + CO2eq.transport.etOH $[\mathrm{gCO} 2 e q]$

\subsubsection{Extra outputs}

Vanuit de reststromen die ontstaan bij de ethanolproductie kan nog DDGS / veevoer en biogas gemaakt worden. Onderstaand de berekeningen om de hoeveelheden hiervan te bepalen.

veevoer $=$ benodigde.hoeveelheid $*$ percentage.eiwit. korrel $/ 100 *$ DS. snijmais [ton]

Vanuit de suikerbietresten na destillatie \& van het snijmaisstro kan biogas $(\mathrm{CH} 4)$ gemaakt worden. Per gewas kan berekend worden hoeveel kuub gas er per ton droge stof gemaakt kan worden: gas.opbrengst $=$ gewas. $C H 4 *$ gewas. ODS $[\mathrm{m} 3 /$ ton $D S]$ 
Dir resulteert in:

biogas. snijmais $=$ areaal.gewas $*$ snijmais. stro $/ 1000 *$ snijmais. gas. opbrengst $\left[\mathrm{m}^{\wedge} 3\right.$ ]

biogas. suikerbiet $=$ benodigde.hoeveelheid $*(D S$. suikerbiet - suikerbiet. suiker.percentage $) / 100 *$

suikerbiet. gas. opbrengst $\left[\mathrm{m}^{\wedge} 3\right]$

\subsubsection{Totale resultaat}

Met bovenstaande formules is berekend hoeveel $\mathrm{CO} 2$ equivalenten de teelt, verwerking, transport en opslag uitstoot. Om de gemiddelde BKG uitstoot van het ethanol gemaakt via zowel het direct processing van suikerbiet als het snijmais fermentatie proces te berekenen is onderstaande formule gebruikt:

(CO2eq. suikerbiet.teelt + CO2eq. suikerbiet.proces + CO2eq. suikerbiet.opslag + CO2. suikerbiet.transport + CO2eq. snijmais. teelt + CO2eq. snijmais.proces + CO2eq. snijmais. transport)/

(suikerbiet.hoeveelheid.etOH.MJ + snijmais.hoeveelheid.etOH.MJ) [gCO2eq/MJ] 


\section{$4 \quad$ Resultaten en discussie}

Aan de hand van de beschreven input waarden en vergelijkingen (hoofdstuk 3) zijn BKG emissies berekend van de ethanol uit suikerbiet en snijmais (hoofdstuk 2). In dit hoofdstuk worden de resultaten van de berekeningen met het beschreven model weergegeven en besproken.

\subsection{Resultaten en discussie op de resultaten}

Tabel 11 Resultaten van de gevoeligheidsanalyse

\begin{tabular}{|c|c|c|c|c|c|c|}
\hline \multirow{2}{*}{$\begin{array}{c}\text { Parameter } \\
\begin{array}{c}\text { Suikergehalte in de } \\
\text { suikerbiet }\end{array}\end{array}$} & \multirow{2}{*}{$\begin{array}{c}\begin{array}{c}\text { Standaard } \\
\text { waarde }\end{array} \\
17.5 \%\end{array}$} & \multicolumn{2}{|c|}{$\begin{array}{c}-10 \% \text { waarde } \\
\text { (gCO2eq/MJ } \\
\text { etOH) }\end{array}$} & \multirow{2}{*}{$\begin{array}{c}\text { standaard } \\
\text { (gCO2eq / } \\
\text { MJ etOH) } \\
23.29\end{array}$} & \multicolumn{2}{|c|}{$\begin{array}{c}+10 \% \text { waarde } \\
\text { (gCO2eq/MJ } \\
\text { etOH) }\end{array}$} \\
\hline & & 23.54 & + $1.07(\%)$ & & 23.10 & $-0.82(\%)$ \\
\hline $\begin{array}{l}\text { Zetmeelgehalte in de } \\
\text { snijmais }\end{array}$ & $80 \%$ & 23.31 & $+0.09(\%)$ & 23.29 & 23.34 & $+0.21(\%)$ \\
\hline $\begin{array}{l}\text { Opbrengst } \\
\text { suikerbieten per } \\
\text { hectare }\end{array}$ & 94.5 ton/ha & 23.66 & + $1.59(\%)$ & 23.29 & 22.98 & - $1.33(\%)$ \\
\hline $\begin{array}{l}\text { Opbrengst snijmais } \\
\text { per hectare }\end{array}$ & 9 ton/ha & 23.54 & + $1.07(\%)$ & 23.29 & 23.09 & $-0.86(\%)$ \\
\hline $\begin{array}{l}\text { Fabriekscapaciteit } \\
\text { suikerbieten per dag }\end{array}$ & 2200 ton/day & 23.25 & $-0.17(\%)$ & 23.29 & 23.33 & $+0.17(\%)$ \\
\hline $\begin{array}{l}\text { Omzetting efficiëntie } \\
\text { suiker naar ethanol } \\
(85 \%-95 \%)\end{array}$ & $90 \%$ & 24.27 & $+4.21(\%)$ & 23.29 & 22.39 & $-3.86(\%)$ \\
\hline $\begin{array}{c}\text { Tarra percentage } \\
\text { suikerbiet (5\%-15\%) }\end{array}$ & $10 \%$ & 23.25 & $-0.17(\%)$ & 23.29 & 23.33 & $+0.17(\%)$ \\
\hline $\begin{array}{l}\text { Verwerkingsdagen } \\
\text { suikerbieten }\end{array}$ & 200 day/year & 23.04 & $-1.07(\%)$ & 23.29 & 23.57 & $+1.20(\%)$ \\
\hline $\begin{array}{c}\text { Percentage } \\
\text { akkerbouw (20\%- } \\
30 \%)\end{array}$ & $25 \%$ & 23.38 & + $0.39(\%)$ & 23.29 & 23.22 & $-0.30(\%)$ \\
\hline
\end{tabular}

Binnen de gestelde grenzen en aannames van het model zijn bovenstaande resultaten gevonden (Tabel 11). Als standaard waarde is een BKG uitstoot van $23.29 \mathrm{gCO} 2$ equivalenten per MJ ethanol gevonden. Dit is het gemiddelde voor het ethanol geproduceerd gedurende het jaar, met 200 dagen suikerbiet en 110 dagen snijmais verwerking. Dit is met biogas en DDGS productie. In Duitsland, waar vanuit diksap ethanol is gemaakt kwam men uit op $38 \mathrm{gCO} 2$ equivalenten per MJ ethanol (Buchspies \& Kaltschmitt, 2016), bij dit proces waren de bijproducten vinasse en geperste bietenpulp. In Duitsland zullen net wat andere omstandigheden spelen qua verbruiken en opbrengsten dan in Nederland, echter dit grote verschil in BKG uitstoot per MJ ethanol zullen deze niet veroorzaken. Het diksap in plaats van direct processing zal hoogst waarschijnlijk een belangrijkere invloed hebben.

Wanneer er meer suiker in de suikerbieten zit zal er meer ethanol geproduceerd worden met dezelfde teelt, opslag en proces. Echter zal er wel meer transport nodig zijn, aangezien er meer ethanol geproduceerd is uit dezelfde hoeveelheid bieten. Daarnaast wordt een groter deel van de totale BKG uitstoot van het proces toegeschreven aan het ethanol productie, door het verhoogde 
suikerpercentage wordt de allocatie factor hoger (zie vergelijking 25 \& 26). Oordelend aan de resultaten weegt de hogere allocatiefactor niet op tegen de verhoogde ethanol opbrengst. Hierdoor is de BKG uitstoot per MJ ethanol lager bij een hoger suikerpercentage en een hogere BKG uitstoot per $\mathrm{MJ}$ ethanol bij een lager suikerpercentage.

Met een hoger zetmeelgehalte in de korrel neemt de BKG uitstoot per MJ ethanol toe. Doordat er een maximum ethanol percentage in de reactor geldt (zie vergelijking $4 \mathrm{t} / \mathrm{m} \mathrm{9}$ ) is er minder hectare snijmais nodig voor dezelfde hoeveelheid ethanol. De totale teelt uitstoot is dus lager, hetzelfde geldt voor het transport. Het transport van snijmaiskorrels kost minder kilometers, de hoeveelheid ethanol getransporteerd blijft gelijk. Er is minder snijmais nodig in het proces dus het proces heeft ook een lagere totale BKG uitstoot. Echter wordt, eveneens als bij de suikerbieten, het percentage wat toe te schrijven is aan de ethanol productie, de allocatiefactor, hoger (zie vergelijking 28 \& 29). Een hoger zetmeel gehalte betekend een verlaging van het restproduct. Oordelend aan de resultaten weegt deze hogere allocatiefactor, in tegenstelling tot bij de suikerbieten, wel op tegen de verminderingen van de totale uitstoot behorende tot de verwerking van de snijmais. Opvallend is, dat ook bij een lager zetmeel percentage een hogere BKG uitstoot per MJ ethanol hoort. Dezelfde redenatie is hierbij te volgen: er is er meer snijmais nodig. Maar, door de allocatie bij het proces is het verschil met de standaard minimaal. De allocatiefactor is een lineaire functie afhankelijk van de benodigde hoeveelheid snijmais, de totale uitstoot van zowel teelt, proces als teelt is ook een lineair afhankelijk van de benodigde hoeveelheid snijmais, de benodigde hoeveelheid snijmais is afhankelijk van het zetmeel gehalte. Dit met elkaar vermenigvuldigd (wat gebeurt in vergelijking 31) levert een exponentieel effect met betrekking tot de uitstoot van het proces bij snijmais ethanol. Vanuit het snijmais blijft de hoeveelheid geproduceerde ethanol constant. Hierdoor ontstaat er een parabool met betrekking tot de uitstoot per MJ ethanol. Per toeval ligt het dal van deze parabool rond de aangenomen standaard waarde.

Met een verhoogde opbrengst aan suikerbieten per hectare verandert de geproduceerde hoeveelheid ethanol niet. Echter is er wel minder land nodig, waardoor de totale teelt uitstoot daalt. Daarnaast is er hierdoor ook minder transport nodig. Dit resulteert in een lagere BKG uitstoot per MJ ethanol bij een hogere opbrengst en een hogere BKG uitstoot per MJ ethanol bij een lagere opbrengst. De door Buchspies \& Kaltschmitt (2016) beschreven uitstoot vanuit de diksap route gaat uit van een opbrengst van 77.6 ton suikerbiet per hectare. Dit is beduidend lager dan de Nederlandse opbrengst van 94.5 ton per hectare. Kijkend naar de $-10 \%$ waarde (85.05 ton per hectare) levert dit $1.76 \%$ meer BKG uitstoot per $\mathrm{MJ}$ ethanol op. Dit versterkt het eerder genoemde statement dat niet alleen de verschillen in teelt en energiemarkt, maar ook het proces, het grote verschil tussen het proces beschreven in dit rapport en het ethanol uit diksap proces zoals beschreven bij Buchspies \& Kaltschmitt veroorzaakt.

Voor de variatie in snijmais opbrengst geldt hetzelfde als voor de suikerbieten opbrengst: bij een hogere opbrengst een lagere BKG uitstoot per $\mathrm{MJ}$ ethanol en bij een lagere opbrengst een hogere BKG uitstoot per MJ ethanol.

Wanneer meer suikerbieten per dag verwerkt kunnen worden stijgt de BKG uitstoot per MJ ethanol. Er zijn in totaal meer suikerbieten nodig, dus de totale emissie van de teelt stijgt, het proces verwerkt meer bieten dus een hogere emissie, er is meer opslag nodig en meer suikerbieten transport en ethanol transport. Aangezien de snijmais capaciteit gekoppeld is aan de suikerbieten capaciteit geldt een hogere suikerbieten verwerking per dag ook tot een hogere snijmaisverwerking per dag, met dezelfde gevolgen. Door de verhoging van de capaciteiten is de ethanol opbrengst lineair hoger. Maar deze weegt niet op tegen de verhoogde uitstoot, doordat bijvoorbeeld het transport niet lineair stijgt (zie vergelijking 18). Bij een hogere fabriekscapaciteit is de BKG uitstoot hoger per MJ ethanol, bij een lagere fabriekscapaciteit is de BKG uitstoot lager per MJ ethanol. In andere woorden een kleinere schaal fabriek is milieutechnisch interessanter.

Door een hogere omzettingsefficiëntie van suiker naar ethanol daalt de BKG uitstoot per MJ ethanol. En bij een lagere omzettingsefficiëntie van suiker naar ethanol stijgt de BKG uitstoot per MJ ethanol. Voor de suikerbieten geldt dat er meer transport van ethanol nodig is bij een verhoogde omzettingsefficiëntie, er meer ethanol wordt geproduceerd. Verder verandert er in het proces dan niets, zodat de hogere productie omgezet kan worden in een lagere footprint. Voor de snijmais geldt 
dat er door een hogere efficiëntie minder snijmais nodig is doordat er hier met een maximale ethanol concentratie gewerkt wordt. En minder grondstof per eenheid geproduceerde ethanol, betaalt zich uit via een lagere BKG emissie per eenheid product.

Bij een verhoogde tarra aan de suikerbieten stijgt de BKG uitstoot per MJ ethanol, terwijl met een verlaagde tarra deze BKG uitstoot daalt. Er hoeft dan immers minder gewicht vervoerd te worden naar de fabriek.

Wanneer er meer dagen suikerbieten verwerkt worden in de fabriek (en dus minder maïs), stijgt de BKG uitstoot per MJ ethanol, wanneer er korter suikerbieten verwerkt worden daalt de BKG uitstoot per $\mathrm{MJ}$ ethanol. Bij een langere verwerking van bieten is er meer van die grondstof en dus teelt nodig, maar minder snijmais teelt. Deze verhoging van suikerbieten en verlaging voor de snijmais geldt ook voor het verwerkingsproces \& transport. Wel is er meer opslag nodig. De totale BKG uitstoot uit suikerbieten neemt dus toe en die uit snijmais neemt dus af. De totale op jaarbasis geproduceerde hoeveelheid ethanol neemt af, dit betekend dat er per tijdseenheid meer ethanol gevormd wordt vanuit snijmais dan vanuit suikerbieten. Dit komt doordat er met suikerbieten een lager percentage ethanol wordt gehaald in de reactor. De reactietijd is wel korter, echter is dit niet in verhouding tot de $14 \%$ ethanol vanuit snijmais. De daling in totale BKG uitstoot gekoppeld aan snijmais ethanol weegt niet op tegen de stijging bij de suikerbieten, aangezien de gemiddelde BKG uitstoot per MJ stijgt bij een langere suikerbieten verwerking. In andere woorden, de BKG uitstoot van een MJ ethanol uit snijmais is lager dan die uit suikerbieten.

Wanneer het mogelijk zou zijn om het hele jaar door suikerbieten op te slaan op de manier zoals nu beschreven in het rapport zou de uitstoot per MJ ethanol uitkomen op $25.38 \mathrm{gCO}$ eq per MJ ethanol. Bij alleen snijmais is de uitstoot $22.14 \mathrm{gCO}$ eq per MJ ethanol. Beide zijn berekend met de 55 onderhoudsdagen per jaar. Dit versterkt de eerdere waarneming dat de BKG uitstoot van een MJ ethanol uit snijmais lager is dan die uit suikerbieten.

Door een hoger percentage akkerbouw in een gebied neemt de BKG uitstoot per MJ ethanol af, bij een lager percentage akkerbouw neemt de BKG uitstoot per MJ ethanol toe. Dit komt doordat bij een hoger percentage akkerbouw de gemiddelde transportafstand van de gewassen afneemt. Per eenheid geproduceerde ethanol zijn dan minder transportkilometers nodig.

Binnen het model zijn er voor de processen aannames gemaakt, bij snijmais is een proces uit de literatuur genomen, voor suikerbieten is het proces zoals nu voor ogen bij DSD genomen. Deze twee processen zijn hoogst onzeker en zeer gevoelig voor variatie. Daarom is de benodigde hoeveelheid stroom en stoom, samengevat als proceswaarden, voor de suikerbiet verwerking gevarieerd. Bij een hoger stroom en stoom verbruik stijgt de BKG uitstoot per MJ ethanol, bij een lager verbruik daalt de BKG uitstoot per MJ ethanol (Figuur 3). 


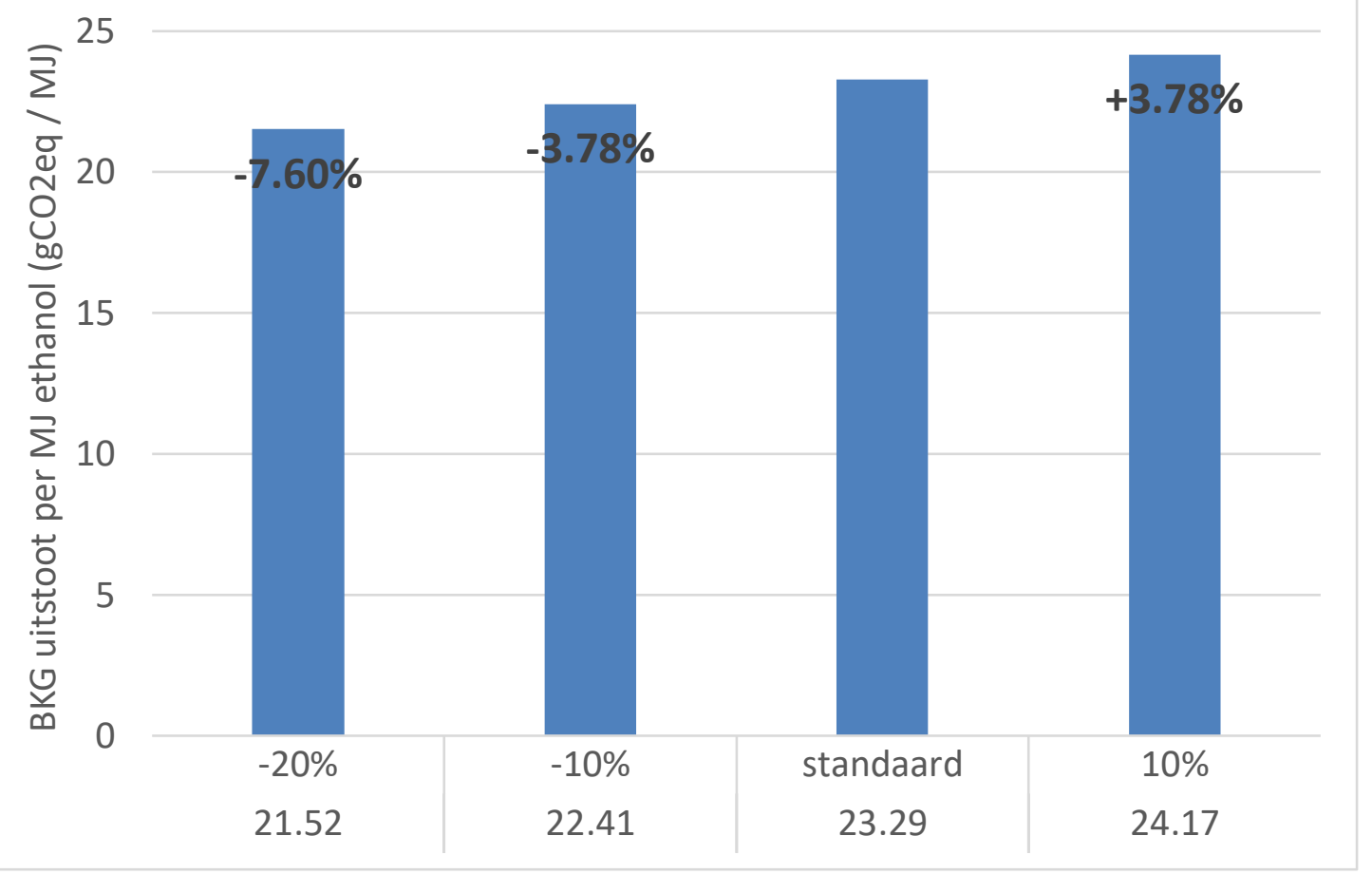

Figuur 3 Verandering van de BKG uitstoot bij variatie van de proceswaarden, onderstaand de absolute waarden in gCO2eq/MJ ethanol

\subsection{Discussie op het model}

Binnen het model zijn bepaalde keuze en aannames gemaakt, een deel van deze heeft een te voorspellen effect, in deze paragraaf worden een aantal van hen behandeld.

Het transport van trekkers en materieel van en naar de akkers zit niet in het dieselverbruik bij de teelt. In het geval dat de akkers ver van de boerderij afliggen kan het transport van en naar de akker significant mee gaan wegen in het totale dieselverbruik c.q. emissies. De inschatting is echter dat dit geen grote veranderingen in bovenstaande gevoeligheid teweeg zal brengen.

Door continue ontwikkelingen in de landbouw sector zullen de input waarden veranderen. Elke 3 jaar komt er een nieuwe KWIN-AGV uit waarmee de teelt specifieke waarden geüpdatet kunnen worden op basis van de dan geldende praktijk. Naar alle waarschijnlijkheid zal door de transitie naar kringlooplandbouw de uitstoot verminderen, wanneer er duurzamere alternatieven voor onder anderen $\mathrm{N}$-kunstmest en diesel zijn. Hierdoor zal de uitstoot per $\mathrm{MJ}$ ethanol dalen.

Echter wanneer meer biologisch geproduceerd gaat worden is er meer arbeid (ook mechanisch) en daarbij meer diesel nodig zijn, wat de uitstoot zal verhogen. Binnen de biologische teelt worden er geen gewasbeschermingsmiddelen of kunstmest gebruikt, wat de uitstoot zal verlagen. Onderzoek in 2007 kwam tot een vergelijkbare teeltuitstoot per kg gewas (Bos et al., 2007) voor de gangbare en biologische teelt. Hoe de standaardwaarde voor de uitstoot in bovenstaande resultaten door deze ontwikkelingen veranderd is lastig te voorspellen.

Wanneer het geproduceerde biogas gebruikt wordt voor de warmte en elektriciteitsvraag van de fabriek en daarnaast ook eventueel voor transport doeleinden gebruikt kan worden, zal de uitstoot van het totale proces naar beneden gaan. Dit komt doordat het biogas een lagere uitstoot waarde heeft dan aardgas. Echter, er kan dan niet meer gealloceerd worden voor de productie van biogas aangezien deze in het proces weer verbruikt wordt. Hierdoor telt de volledige uitstoot van het proces mee. 
Wanneer er voor een andere bron van elektriciteit gekozen kan worden kan de BKG uitstoot per kWh dalen. Bij 100\% wind, zon of waterkracht stroom daalt de rekenkundige uitstoot naar $0 \mathrm{gCO}$ eq / kWh (Milieucentraal \& Stimular, 2020). Een bedrijf kan hiervoor kiezen door het inkopen van "Garanties van Oorsprong" (GVO's). Wanneer dit gedaan wordt neemt de BKG uitstoot per MJ ethanol af.

Alloceren is in dit model alleen gedaan naar economisch interessante producten, zoals biogas en DDGS. Deze producten worden ook nu op de markt verkocht en gebruikt.

Binnen dit model is het droge stof gehalte van suikerbieten als vaste waarde genomen. Wanneer het suiker gehalte stijgt, wordt het droge stof gehalte niet hoger. Reëler zou zijn dat het droge stof gehalte mee stijgt. Doordat het in deze niet stijgt betekent het dat er minder biogas geproduceerd wordt omdat hiervoor eenvoudigweg minder organisch materiaal beschikbaar is. Dit heeft als gevolg dat de allocatiefactor, die gebaseerd is op Lower Heating Value, ten opzichte van de ethanol hoger wordt.

Als aanname zijn de teeltbenodigdheden vanuit Flevoland genomen. Echter, er zijn ook andere teeltgebieden in Nederland waar suikerbieten en snijmaïs geteeld worden: Noord-Oost, Zuid-Oosten Zuid-West Nederland. In Tabel 12 \&

Tabel 13 zijn de bijbehorende opbrengsten en gebruikte inputs opgenomen, in combinatie met de bijbehorende uitstoot berekend volgens vergelijking 19 gedeeld door de opbrengst.

Tabel 12 Gemiddelde teeltbenodigdheden \& bijbehorende CO2 uitstoot in verschillende gebieden voor suikerbiet per hectare (KWIN 2018)

\begin{tabular}{|c|c|c|c|c|c|c|c|c|c|}
\hline Suikerbiet & $\begin{array}{l}\text { Opbrengst } \\
\text { (kg) }\end{array}$ & $\begin{array}{l}\text { Diesel } \\
\text { (I) }\end{array}$ & $\begin{array}{l}\text { N- } \\
\text { kunst } \\
\text { mest } \\
\text { (kg) }\end{array}$ & $\begin{array}{l}\text { P- } \\
\text { kunst } \\
\text { mest } \\
\text { (kg) }\end{array}$ & $\begin{array}{l}\text { K- } \\
\text { kunst } \\
\text { mest } \\
\text { (kg) }\end{array}$ & $\begin{array}{l}\text { Herb } \\
\text { icide } \\
(\mathbf{k g})\end{array}$ & $\begin{array}{l}\text { Fung } \\
\text { icide } \\
(\mathbf{k g})\end{array}$ & $\begin{array}{l}\text { Insect } \\
\text { icide } \\
(\mathbf{k g})\end{array}$ & $\begin{array}{l}\text { Uitstoot } \\
\text { (gCO2eq } \\
\text { / kg) }\end{array}$ \\
\hline $\begin{array}{l}\text { Flevoland } \\
\text { (kleigrond) }\end{array}$ & 94500 & 122 & 150 & 60 & 50 & 10.5 & 2 & 2 & 13.4 \\
\hline $\begin{array}{l}\text { N-Nederland } \\
\text { (kleigrond) }\end{array}$ & 80400 & 116 & 150 & 60 & 60 & 9 & 2 & 2 & 15.7 \\
\hline $\begin{array}{l}\text { N-Nederland } \\
\text { (zand- en } \\
\text { dalgrond) }\end{array}$ & 75100 & 114 & 145 & 50 & 160 & 9 & 2 & 2 & 16.9 \\
\hline $\begin{array}{l}\text { ZO- } \\
\text { Nederland } \\
\text { (zandgrond) }\end{array}$ & 79000 & 114 & 116 & 50 & 140 & 8.5 & 2 & 2.5 & 13.2 \\
\hline $\begin{array}{l}\text { ZW- } \\
\text { Nederland } \\
\text { (kleigrond) }\end{array}$ & 83750 & 119 & 150 & 60 & 50 & 12 & 2 & 2 & 15.3 \\
\hline
\end{tabular}


Tabel 13 Gemiddelde teeltbenodigdheden \& bijbehorende CO2 uitstoot in verschillende gebieden voor snijmais per hectare (KWIN 2018)

\begin{tabular}{|c|c|c|c|c|c|c|c|c|c|}
\hline Snijmais & $\begin{array}{l}\text { Opbrengst } \\
\text { (kg) }\end{array}$ & $\begin{array}{l}\text { Diesel } \\
\text { (I) }\end{array}$ & $\begin{array}{l}\text { N- } \\
\text { kunst } \\
\text { mest } \\
(\mathrm{kg})\end{array}$ & $\begin{array}{l}\text { P- } \\
\text { kunst } \\
\text { mest } \\
(\text { kg) }\end{array}$ & $\begin{array}{l}\text { K- } \\
\text { kunst } \\
\text { mest } \\
(\mathrm{kg})\end{array}$ & $\begin{array}{l}\text { Herb } \\
\text { icide } \\
(\mathbf{k g})\end{array}$ & $\begin{array}{l}\text { Fung } \\
\text { icide } \\
\text { (kg) }\end{array}$ & $\begin{array}{l}\text { Insect } \\
\text { icide } \\
(\mathbf{k g})\end{array}$ & $\begin{array}{l}\text { Uitstoot } \\
\text { (gCO2eq } \\
\text { / kg) }\end{array}$ \\
\hline $\begin{array}{l}\text { Kleigrond } \\
\text { (Flevoland } \\
\text { \& ZW- } \\
\text { Nederland) }\end{array}$ & 56200 & 72 & 160 & 60 & 0 & 3.1 & 0 & 0 & 22.4 \\
\hline $\begin{array}{l}\text { Zandgrond } \\
\text { (NO \& ZO- } \\
\text { Nederland) }\end{array}$ & 47700 & 92 & 112 & 50 & 70 & 4 & 0 & 0 & 19.5 \\
\hline
\end{tabular}

Uit Tabel 12 \&

Tabel 13 kan geconcludeerd worden dat de uitstoot wat betreft de teelt varieert per gebied. Een hogere BKG uitstoot per kg gewas zal leiden tot een hogere BKG uitstoot per MJ ethanol en een lagere BKG uitstoot per $\mathrm{kg}$ gewas tot een lagere BKG uitstoot per MJ ethanol.

Daarnaast zijn wellicht niet alle gebruikte in puts meegenomen, wanneer dit het geval is zal de BKG uitstoot per kg gewas hoger uitvallen.

Daarnaast is aangenomen dat alle landbouwgrond in het gebied rondom de fabriek suikerbieten teelt met een rotatie van 4 maar daarnaast ook nog snijmais met een rotatie van 1 . Dit beide doen is om te beginnen niet mogelijk. Bovendien zal ook niet iedereen deze gewassen telen. Hierdoor is het transport te laag ingeschat en zal de werkelijke BKG uitstoot per MJ ethanol hoger uitvallen.

De BKG uitstoot van de verwerking van suikerbieten is gebaseerd op de berekeningen van TechnipFMC. Deze berekeningen zijn gebaseerd op meetwaardes gevonden in de pilot opstelling waarin ongeveer $700 \mathrm{~kg}$ bieten per batch werd verwerkt (Kootstra 2017; Sorgedrager \& de Koning 2019). Mede daarom zijn de gebruikscijfers van energie tijdens de processing met onzekerheid omgeven. Met het beschreven model is ingeschat wat de consequenties zijn van aanpassingen in het energieverbruik (zie Figuur 3).

De BKG uitstoot van de verwerking van snijmais is gebaseerd op een proces in Iowa (USA). Wanneer hier met een andere stroom mix, met gas met een andere calorische waarde gewerkt wordt of met een ander proces kan de waarde hoger of lager uitvallen. Wanneer de energiemix meer BKG uitstoot heeft zal ook de BKG uitstoot per MJ ethanol hoger uitvallen. Wanneer de calorische waarde hoger is zal de BKG uitstoot per MJ ethanol daarentegen lager uitvallen. 


\section{Conclusie \& aanbevelingen}

Het direct processing van suikerbieten en daarnaast snijmais fermenteren waarbij biogas en DDGS geproduceerd wordt vanuit de reststromen heeft een BKG uitstoot van $23.29 \mathrm{gCO}$ eq per MJ ethanol, wanneer er met de beschreven standaardwaarden gewerkt wordt. Hiermee scoort het proces beter ten opzichte van de RED. Suikerbiet ethanol met biogas productie heeft een default waarde van 23.9 gCO2eq per MJ ethanol en snijmais ethanol een default waarde van $55.2 \mathrm{gCO}$ eq per MJ ethanol in de RED. De waarden van het ontworpen proces zijn lager dan de default waarden van de RED.

Uit Tabel 11 kan geconcludeerd worden dat er verschillende parameters zijn met een grote invloed op de BKG uitstoot per MJ ethanol. Het grootste effect wordt veroorzaakt door een verschil in de omzetting efficiëntie van suiker naar ethanol. Dat betekend dat het proces zo efficiënt mogelijk gemaakt moet worden. Echter, niet alleen qua omzetting, ook qua energieverbruik. Een hoger of lager energieverbruik binnen het proces heeft een grote invloed op de BKG uitstoot per MJ ethanol. Het formaat van de fabriek speelt ook een grote rol, hoe kleiner hoe lager de uitstoot per MJ ethanol. Daarnaast is een zo hoog mogelijke opbrengst per hectare voordelig voor de BKG uitstoot per MJ ethanol. Het suiker gehalte in de suikerbiet dient ook hoger te zijn voor een lagere BKG uitstoot, dit betekent dat hier in de teelt (eventueel met behulp van veredeling) en opslag in gestuurd moet worden. De parameters met het grootste effect zijn echter niet simpel in te stellen, dit zal gestuurd moeten worden door onderzoek te blijven doen en te kijken naar wat er veredeling technisch en proces technisch mogelijk is. Het effect op de financiële kant van de ethanol productie is niet meegenomen in deze studie, echter wel relevant wanneer men daadwerkelijk het in dit rapport beschreven productieproces wilt gaan realiseren. 


\section{Literatuur}

Balat, Mustafa, and Havva Balat. "Recent trends in global production and utilization of bio-ethanol fuel." Applied energy 86, no. 11 (2009): 2273-2282.

Beer, Tom, Tim Grant, Geoff Morgan, Jack Lapszewicz, Peter Anyon, Jim Edwards, Peter Nelson, H. Watson, and David Williams (2001). "Comparison of transport fuels: life-cycle emissions analysis of alternative fuels for heavy vehicles." Australia): Australian Greenhouse Office.

Bos, J. F. F. P., De Haan, J. J., \& Sukkel, W. (2007). Energieverbruik, broeikasgasemissies en koolstofopslag: de biologische en gangbare landbouw vergeleken. Volledig rapport (No. 140). Plant Research International.

Buchspies, B., \& Kaltschmitt, M. (2016). Life cycle assessment of bioethanol from wheat and sugar beet discussing environmental impacts of multiple concepts of co-product processing in the context of the European Renewable Energy Directive. Biofuels, 7(2), 141-153.

Dueck, T. A., Elings, A., Kempkes, F. L. K., Knies, P., van de Braak, N. J., Victoria, N. G., ... \& van Noort, F. R. (2004). Energie in kengetallen: op zoek naar een nieuwe balans: basisdocument (No. 312). Plant Research International.

Edwards, R., Padella, M., Giuntoli, J., Koeble, R., O'Connell, A., Bulgheroni, C., \& Marelli, L. (2017). Definition of Input Data to Assess GHG Default Emissions from Biofuels in EU Legislation, Version 1cJuly2017.

Eggleston, H S, Buendia, L, Miwa, K, Ngara, T, and Tanabe, K. 2006 IPCC Guidelines for National Greenhouse Gas Inventories. Japan: N. p., 2006. Web.

Engineeringtoolbox.com, Ethanol - Thermophysical properties, https://www.engineeringtoolbox.com/ethanol-ethyl-alcohol-properties-C2H6O-d_2027.html last visited on 06-05-2020 11:30h

Engineeringtoolbox.com, Steam, Properties of Saturated Steam - SI Units, https://www.engineeringtoolbox.com/saturated-steam-properties-d_101.html last visited on 06-05-2020 11:00 h.

Engineeringtoolbox.com, Water, Density, Specific Weight and Thermal Expansion Coefficient, https://www.engineeringtoolbox.com/water-density-specific-weight-d_595.html last visited on 06-05-2020 11:00 h.

ePure, 2018, Share of European renewable ethanol produced from each feedstock type, infographic

EU (2018). Directive (EU) 2018/2001 of the European Parliament and of the Council of 11 December 2018 on the promotion of the use of energy from renewable sources. Official Journal of the European Union, 5, 82-209.

Howard, N., Edwards, S., \& Anderson, J. (1999). Methodology for environmental profiles of construction materials, components and buildings. BRE Report BR 370. Watford.

Kaltschmitt, M., \& Reinhardt, G. A. (1997). Nachwachsende Energieträger-Grundlagen, Verfaben, Ökologische Bilanzierung (Renewable Energy Sources, Basis, Processes and Ecological Balance).

Kamp, J. A. L. M., \& Montsma, M. P. (2013). Bewaring aardappelen met koeling \& ventileren. PPO AGV. 
Kootstra, A.M.J., 2017. Direct processing of sugar beet using Betaprocess; Chembeet WP1 and WP2. Wageningen Research, Report WPR-744

Kootstra, L. 2018, 20 LCA's van brandstof-machinecombinaties, TNO 2018 R10658

KWIN, AGV (2018). Kwantitatieve Informatie Akkerbouw en Vollegrondsgroenteteelt 2018.

Liska, A. J., Yang, H. S., Bremer, V. R., Klopfenstein, T. J., Walters, D. T., Erickson, G. E., \& Cassman, K. G. (2009). Improvements in life cycle energy efficiency and greenhouse gas emissions of cornethanol. Journal of Industrial Ecology, 13(1), 58-74.

Lizotte, P. L., Savoie, P., \& De Champlain, A. (2015). Ash content and calorific energy of corn stover components in Eastern Canada. Energies, 8(6), 4827-4838.

Milieucentraal \& Stimular, 2020. Notitie CO2-emissiefactoren stroom. 21 januari 2020

Mortimer, N., Cormack, P., Elsayed, M., \& Horne, R. (2003). Evaluation of the comparative energy, global warming and social costs and benefits of biodiesel. Report, Resource Research Unit, Sheffield Hallam University, UK.

Otten, M., Hoen, M., \& den Boer, E. (2017). STREAM Goederenvervoer 2016. Emissies van Modaliteiten in Het Goederenvervoer.

Rector, R (2015), De suikerbiet kan meer. Wageningen World 03-2015, 22-25

Schipperus, R., Spruijt, J., (2013). EnergieRijk: Deelproject decentrale bioethanol productie.

Sorgedrager, M. J. \& de Koning, P. (2019). Pilot Study: Direct BETA Processing Sugar Beet to Ethanol, Final report fermentation.

Turhollow, A. F., \& Heady, E. O. (1986). Large-scale ethanol production from corn and grain sorghum and improving conversion technology. Energy in agriculture, 5(4), 309-316.

De Visser, C. L. M. \& Spruijt, J. (2013). DigestEconomics v2.3 Economic model codigestion for electricity or green gas with or without TDH pre-treatment

Wijnholds, K. H., Groten, J. A. M., van der Voort, M. P. J., Kamp, J. A. L. M., \& Timmer, R. D. (2010). Energiekompas voor de Veenkoloniën: eindrapport onderzoek 2007-2009. PPO AGV.

Woltjer, G., Daioglou, V., Elbersen, B., Ibañez, G. B., Smeets, E. M. W., González, D. S., \& Barnó, J. G. (2017). Study report on reporting requirements on biofuels and bioliquids stemming from the directive (EU) 2015/1513. EU Commission. 


\section{Bijlagen}

Bijlage 1: Energieberekeningen

Bijlage 2: Energieberekeningen snijmaisfermentatie proces 


\section{Bijlage 1 Energieberekeningen Betaprocess}

Door TechnipFMC BV in opdracht van DSD BV is een energieberekening gemaakt van het de suikerbietenverwerking met gebruik van het Betaprocess. 


\section{(PRELIMINARY) UTILITIES \\ CONSUMPTION SUMMARY}

Client : DSD

Location :

Plant : Ethanol Full Scale Plant (83 t/h)

\begin{tabular}{|c|c|c|c|c|c|c|c|}
\hline \\
\hline 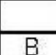 & 11 oct 19 & \multirow{2}{*}{\multicolumn{2}{|c|}{ Preliminary }} & MWAN & & & \\
\hline $\mathrm{A}$ & 23.Aug. 19 & & & MNAN & & & \\
\hline \multirow[t]{2}{*}{ REV. } & DATE & MODFFICATIONS & & Dwo & снЕск & SPEC.ENG & PвоJ . MaN. \\
\hline & $\mathrm{TE}$ & $\mathrm{MC}$ & \multicolumn{5}{|c|}{ COVER PAGE } \\
\hline & & 000000000 & \multicolumn{5}{|c|}{$\mathrm{CN}, 0000,000,{ }^{\prime}, 001,002{ }_{\mathrm{B}}^{\mathrm{Re}}$} \\
\hline
\end{tabular}




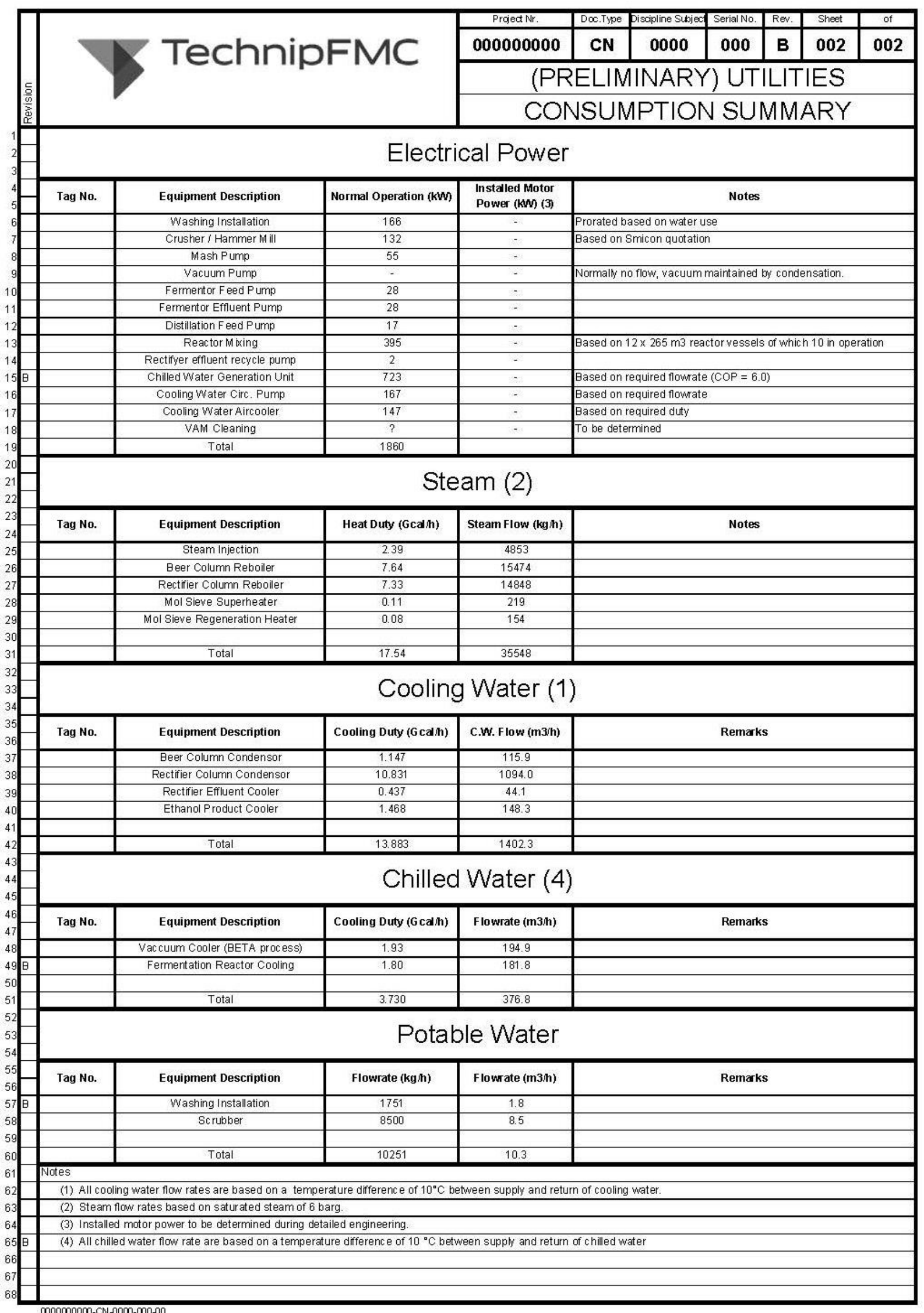

This document or drawing is the property of TECHNIP BENELUX B.V. and shall not, under any circumstances, be totally or partially, directly or indirectly, transferred, reproduced, copied, disclosed or used without TECHNIP BENELUX B.V.'s prior written consent. 


\title{
Bijlage 2 Energieberekeningen snijmaisfermentatie proces
}

\begin{abstract}
Aangezien er geen proeven bekend zijn voor het specifieke snijmais fermentatie proces is er gekeken naar de literatuur. Er zijn globaal gezien twee processen om snijmais naar ethanol om te zetten: dry milling \& wet milling. Het dry milling proces bestaat uit het malen van de snijmais korrels om het ontstane meel vervolgens in de fermentatietank te gebruiken. Het wet milling proces is een stuk uitgebreider: Eerst wordt de snijmais voor 20-48h geweld in water met toevoegingen van sulfurdioxide. Hierbij komen eiwit, oplosbare suikers, vitaminen en mineralen vrij. Vervolgens wordt de snijmais licht opgemaald, hierna wordt het met cyclonen de kiemen gescheiden van de rest. De resten worden vervolgens nogmaals gemaald. Hierdoor kan de vezel fractie opgevangen worden. Wat niet opgevangen wordt, wordt ingedikt en gecentrifugeerd. Een van de stromen wordt gedroogd als gluten meel, het andere deel is een zetmeel stroom. Deze kan nog gedroogd worden of direct gebruikt. Het wet milling proces levert naast een zetmeel stroom dus ook gluten meel, losse snijmais kiemen (voor olie) \& nutrient rijk water (Eckhoff et al., 2003).

Binnen dit project is gekozen voor dry milling, aangezien dit minder apparatuur vereist.
\end{abstract}

In Liska (et al., 2009) is een dry milling proces in Iowa gebaseerd op aardgas en stroom doorgerekend. Uit deze berekeningen volgt dat er per $\mathrm{MJ}$ ethanol $19.7 \mathrm{gCO}$ eq vanuit aardgas komt en 6.53 uit stroom. Een totaal van $26.23 \mathrm{gCO} e \mathrm{eq} / \mathrm{MJ}$ ethanol.

Er is een omzetting van 0.393 I ethanol / $\mathrm{kg}$ snijmais. Ethanol heeft een dichtheid van $785.3 \mathrm{~kg} / \mathrm{m}^{3}$ en een energie dichtheid van $29017 \mathrm{MJ} /$ ton. Hieruit volgt een energiedichtheid per liter van:

$$
29017 / 1000 * 785.3 / 1000=22.78[M J / l]
$$

Dit betekend een omzetting van:

$$
0.393 * 22.78=8.95[\mathrm{MJ} / \mathrm{kg} \text { snijmais }]
$$

Dit betekend een uitstoot van:

$$
26.23 * 8.95=234.9[\mathrm{gCO} e \mathrm{eq} / \mathrm{kg} \text { snijmais }]
$$

Met deze waarde van 234.83 gCO2eq per $\mathrm{kg}$ snijmais zal worden gerekend. 


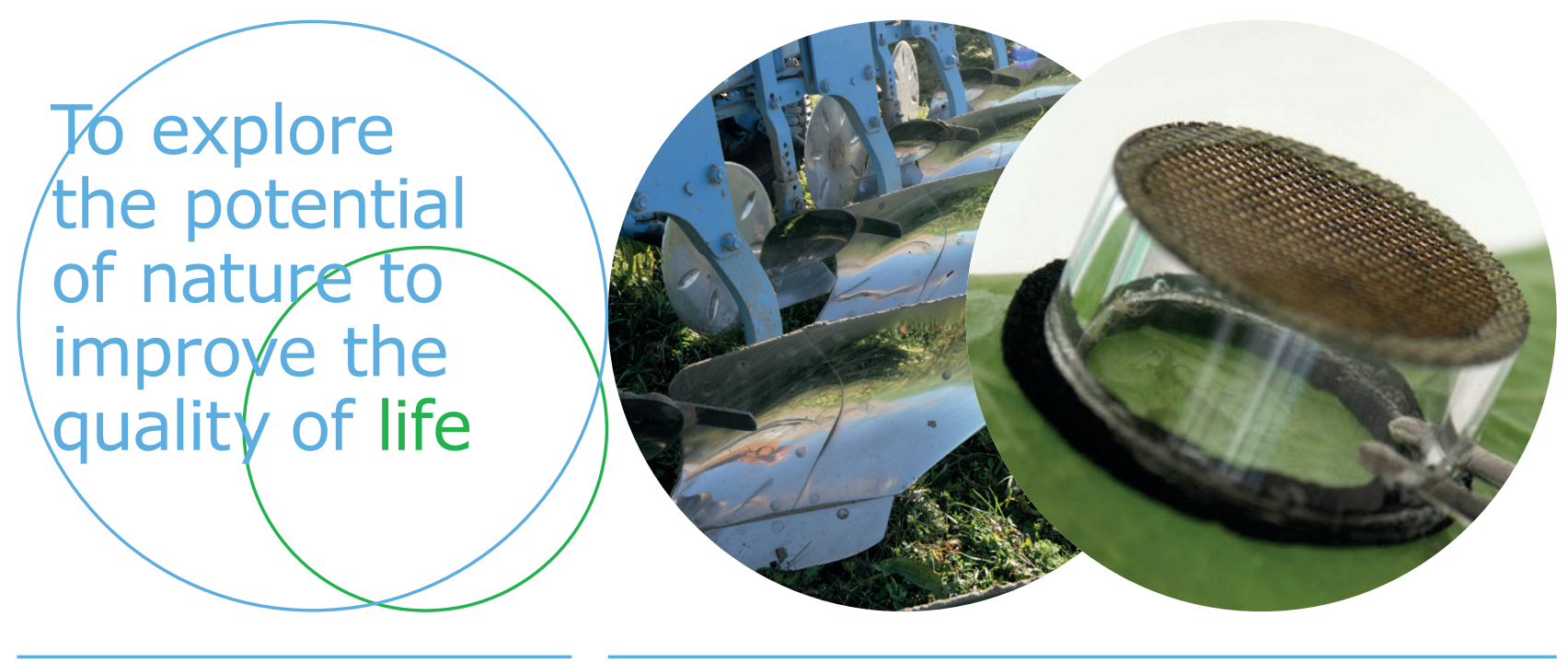

Wageningen University \& Research

\section{Open Teelten | ACRRES}

Edelhertweg 1

Postbus 430

8200 AK Lelystad

T (+31)320 291111

\section{wWw.wur.nI/openteelten}

Rapport WPR-849
The mission of Wageningen University \& Research is "To explore the potential of nature to improve the quality of life". Under the banner Wageningen University \& Research, Wageningen University and the specialised research institutes of the Wageningen Research Foundation have joined forces in contributing to finding solutions to important questions in the domain of healthy food and living environment. With its roughly 30 branches, 6,500 employees (5,500 fte) and 12,500 students, Wageningen University \& Research is one of the leading organisations in its domain. The unique Wageningen approach lies in its integrated approach to issues and the collaboration between different disciplines. 